\title{
Spatiotemporal distribution of bacterioplankton functional groups along a freshwater estuary to pelagic gradient in Lake Michigan
}

\author{
Masanori Fujimoto ${ }^{\mathrm{a}}$, Joann Cavaletto ${ }^{\mathrm{b}}$, James R. Liebig ${ }^{\mathrm{b}}$, Ann McCarthy ${ }^{\mathrm{a}}$, Henry A. \\ Vanderploeg ${ }^{\mathrm{b}}$, and Vincent J. Denef ${ }^{\mathrm{a}^{*}}$ \\ ${ }^{a}$ Department of Ecology and Evolutionary Biology, University of Michigan, Ann Arbor, \\ MI, 48109 \\ ${ }^{\mathrm{b}}$ NOAA Great Lakes Environmental Research Laboratory, Ann Arbor, MI 48108 \\ Corresponding author: vdenef@umich.edu
}




\begin{abstract}
Freshwater bacteria play key roles in biogeochemical cycling and contribute significantly to biomass and energy fluxes. However, studies of Great Lakes ecosystem dynamics often omit bacteria. Here, we used high throughput sequencing to analyze how bacterial diversity and community composition (BCC) vary seasonally along the long term Muskegon estuary to pelagic research transect. Diversity was higher in the estuary than Lake Michigan, in spring compared to summer, and for particle-associated (PA) relative to free-living (FL) fractions. PA communities were distinct from, and more variable than FL communities. For both fractions, spring BCC was more similar between estuary and nearshore Lake Michigan compared to offshore waters. In summer and fall, nearshore and offshore BCC were more similar compared to estuary BCC. Most abundant taxa were inferred to be chemoorganoheterotrophs. While, as a whole, this functional group only showed habitat preference for the PA fraction, we observed phylum and class-level seasonal and spatial preferences. Chemoorganoheterotrophs that also perform bacteriorhodopsin-mediated phototrophy, such as acI Actinobacteria and LD12, strongly preferred FL fractions. Photoautotrophs (Cyanobacteria) were least abundant in spring, when mixotrophic methylotrophs were more abundant, particularly in the estuary. Organisms with chemolithotrophic capabilities, including a mixotrophic, highly abundant Limnohabitans (Lhab-
\end{abstract} A1) OTU, showed limited spatiotemporal patterns. One exception was Nitrosospira, an autotrophic ammonium oxidizer, which peaked in deep offshore waters in fall. Nitrosopira cooccurred with Chloroflexi CL500-11, which likely mineralizes nitrogen-rich organic matter in deep waters. These spatiotemporal BCC shifts suggest differences in bacterially mediated elemental cycling along estuary to pelagic gradients in Lake Michigan.

Keywords: bacterioplankton, seasonal succession, functional groups, biogeochemistry, 16S 


\section{Introduction}

Bacteria play fundamental roles in freshwater community ecology and ecosystem functioning. Community dynamics are influenced by large bacterial biomass fluxes that support the higher food web via zooplankton grazing (Cole et al., 1988; Cotner and Biddanda, 2002; Scavia and Laird, 1987). Ecosystem functioning is affected as bacteria are key determinants of nutrient concentrations and fluxes by fixing carbon and nitrogen, assimilating and remineralizing dissolved and particulate organic matter, and oxidizing and reducing a range of other elements (Falkowski et al., 2008). As an example of the importance of bacteria to global elemental cycles, bacterial respiration of terrestrial carbon subsidies contributes to global net freshwater $\mathrm{CO}_{2}$ emissions that rival net uptake by the oceans despite the relatively small footprint of freshwater systems (Cole et al., 2007; Tranvik et al., 2009).

The advent of high-throughput sequencing now allows for in-depth surveys of these highly diverse bacterial communities, which are now being performed across a variety of aquatic systems, including the Great Lakes (Beall et al., 2016; DeLong et al., 2006; Sogin et al., 2006; Jones et al., 2009; Fisher et al., 2015; Mou et al., 2013; Newton and McLellan, 2015; Rozmarynowycz, 2014; Wilhelm et al., 2014). Yet, despite the ecological importance of bacteria, they are often not included in food web surveys and models. Case in point is the transect that runs from the Muskegon Lake drowned river mouth estuary to the pelagic Lake Michigan environment, which has been studied for over two decades (Madenjian et al., 2002; Millie et al., 2002; Pothoven and Fahnenstiel, 2014) and has been key in determining ecological impacts due to system level disturbances such as dreissenid mussel invasion (Fahnenstiel et al., 2010; Madenjian et al., 2002; Vanderploeg et al., 2010) and nutrient loadings (Dila and Biddanda, 
2015; Gillett and Steinman, 2011; Marko et al., 2013; Weinke et al., 2014). However, until now, comprehensive studies of bacterial communities have been omitted from analyses of this system.

The Laurentian Great Lakes have nearly 3,000 river mouth systems, which are of increasing importance to overall system functioning since the invasion of dreissenid mussels has depleted pelagic production in most of the Great Lakes (Johengen et al., 2008; Larson et al., 2013; Turschak et al., 2014). As habitat filtering exerts strong influence on the distributions of bacterial populations (Lindström and Langenheder, 2012), the changes in resource availability existing along river mouth to pelagic gradients (Dila and Biddanda, 2015; Marko et al., 2013) are expected to drive changes in BCC (Jones et al., 2009; Kritzberg et al., 2006). Freshwater estuaries, which are adjacent to terrestrial environments, serve as a direct drainage of watersheds to the lakes and receive allochthonous organic carbon and other nutrients of terrestrial origin into the system (Larson et al., 2013; Marko et al., 2013). Impact of land use decreases with distance from the shore leading to declining productivity from the estuary to the pelagic environment (Dila and Biddanda, 2015). Similarly, light penetration in the shallow nearshore environments supports the growth of benthic vegetation, while benthic primary production approaches zero in deep offshore environments. In addition to these large spatial gradients, microheterogeneity is created by the presence of particulate matter. While often omitted from BCC analyses, evidence is mounting, including from the Great Lakes (Mou et al., 2013), that strong differences exist between free-living bacterial communities that rely more on dissolved organic matter and those associated with particulate matter, which includes phytoplankton, small zooplankton and other biotic and abiotic particles (Grossart, 2010).

In addition to spatial gradients, seasonality is also expected to affect $\mathrm{BCC}$, due to variation in light, temperature, nutrients and phenology (seasonal cycle) of aquatic and terrestrial 
life (Ghiglione et al., 2007; Ghiglione and Murray, 2012; Kritzberg et al., 2006). Spring snow melt runoff carries allochthonous carbon and terrestrial bacterial populations into the estuary and near shore aquatic systems (Crump et al., 2003). Severe storm events in spring months also resuspend sediments and increase turbidity and water column nutrient concentrations (Johengen et al., 2008; Vanderploeg et al., 2007). In summer months, primary production reaches its peak, which in turn stimulates bacterial secondary production (Bird and Kalff, 1984; Morán et al., 2001; Obernosterer et al., 2008; Scheibner et al., 2014). Leaf litter enters streams in fall serving as resources to estuary and near shore environments (Abelho, 2001; Dila and Biddanda, 2015). In winter, organic resources synthesized in summer productive months are degraded into smaller molecules and they are utilized by a variety of bacterial heterotrophs (Ghiglione and Murray, 2012; Grzymski et al., 2012). The effect of seasonality on BCC is likely not uniform as pelagic environments may be less affected by phenology of terrestrial plants and the seasonal weather events yet are impacted more by the thermal stratification in the summer and early fall and thus creating resource variation along the depth profile (Anadón et al., 2002; Schneider et al., 2003; Turner, 2015).

In this study, we aimed to address the knowledge gap of how these existing resource gradients along river mouth to pelagic gradients in the Great Lakes impact bacterial diversity and BCC. We collected 24 water samples in 2013 along the Great Lakes Environmental Research Laboratory's (GLERL) Lake Michigan long-term research (LTR) transect near Muskegon, MI to describe free-living and particle-associated fraction bacterial communities across time (spring, summer and fall) and space (estuary, nearshore, and offshore at different depths). Bacterial communities were analyzed by high-throughput sequencing of the V4 region of the 16S rRNA gene. The Laurentian Great Lakes account for 18\% of Earth's surface freshwater and are subject 
to multiple stressors, such as coastal eutrophication (Dila and Biddanda, 2015; Larson et al., 2013; Steinman et al., 2008) and species invasions (Allan et al., 2013; Smith et al., 2015; Vanderploeg et al., 2010). Gathering an understanding of the current composition of Great Lakes microbial communities and the factors that affect their distribution is necessary to better understand biogeochemical cycles within these systems, and how these may be affected by environmental stressors.

\section{Methods}

Study site and sample collection. Water samples were collected on board of the R/V Laurentian as a part of NOAA GLERL's LTR ecological monitoring program near Muskegon, MI. Twenty-four sampling events occurred at offshore (M110: 43 11' 59" N, 86 34' 11" W) and nearshore (M15: 43 11' 17" N, 86 20' 38" W) stations of the NOAA's LTR transect, and adjacent Muskegon Lake (estuary of Lake Michigan) near the Grand Valley State University Annis Water Resources Institute monitoring buoy (MLB; www.gvsu.edu/wri/buoy/; 43 14' 17" $\mathrm{N}, 86^{\circ} 16^{\prime} 49^{\prime \prime} \mathrm{W}$ ). Samples were taken during spring (April 23-24), summer (July 15-16), and fall (September 23-24) 2013 at 2-5 $\mathrm{m}$ below the surface and 2-5 $\mathrm{m}$ above the lake floor (Fig. 1, Table 1). The sites in Lake Michigan are the same sites used by Denef et al. (2016) to characterize Chloroflexi abundance and function. During the summer sampling, water samples were also collected from a deep-chlorophyll maximum (DCM) layer (35 m) at the M110 station. We used one 30 L Niskin sampler to collect water, which was poured through $210 \mu \mathrm{m}$ and 20 $\mu \mathrm{m}$ mesh to remove large phyto- and zooplankton (and their associated microbial communities) into a 10 L carboy. Carboys, funnels, and mesh were bleached and MilliQ water rinsed, and rinsed twice with sample water before use. Pre-filtered water was sequentially filtered onto 3.0 
$\mu \mathrm{m}$ polycarbonate filters and $0.22 \mu \mathrm{m}$ polyethersulfone filter membranes (142 $\mathrm{mm}$, Millipore) using a Masterflex I/P peristaltic pump (Cole Parmer) between settings 11-13. Filters were folded with bacterial biomass facing inwards and submersed into RNAlater (Ambion). Sample filtering was limited to 10 minutes and the filtered water volumes varied between $2.8 \mathrm{~L}$ and $11 \mathrm{~L}$ (Table 1). All samples were stored in RNAlater within 20 minutes of sampling. Samples were stored at $-20{ }^{\circ} \mathrm{C}$ on board and transferred to a $-80{ }^{\circ} \mathrm{C}$ freezer within $48 \mathrm{~h}$ of sampling.

Physical and geochemical analyses. At each station, vertical profiles of physical variables were obtained by lowering an instrument package containing a Sea-Bird CTD (conductivity, temperature, depth profiler), oxygen sensor, and fluorometer, and a Biospherical Instruments PAR sensor. In addition, a plankton survey system (PSS) was continuously lowered and raised at $\sim 0.25 \mathrm{~m} \mathrm{~s}^{-1}$ in a sinusoidal path from 1-2 m beneath the lake surface to 2-4 m above the bottom as the $\mathrm{R} / \mathrm{V}$ Laurentian moved at $\sim 1.8 \mathrm{~m} \mathrm{~s}^{-1}$ while logging data every 0.5 second (Vanderploeg et al., 2009). The PSS contained multiple sensors mounted on a V-fin, of which chlorophyll $a$ (Wet Labs ECO Fluorometer, Sea-Bird Scientific), and temperature were used to reconstruct the profiles in Figure 1. The sinusoidal path can be seen in the Figure 1 D-F and contour plots of all the PSS variables were created in IDL (ITT Visual Information Solutions, Boulder, CO, USA) using nearest neighbor interpolation with negative exponential weighting. The fluorometer output (volts) was converted to derived chlorophyll $a$ (chla) concentrations by regression between fluorometer output and laboratory chlorophyll $a$ measurements. Temperature and derived chla data from the Muskegon Lake buoy were downloaded from the Muskegon Lake Buoy Observatory website (www.gvsu.edu/buoy/; Prof. B. Biddanda, Annis Water Resources Institute, Grand Valley State University). 
Duplicate water samples were collected and analyzed for chla, dissolved and particulate organic carbon (DOC, POC), particulate organic nitrogen (PON), total and particulate phosphorus (TP, PP), total suspended solids (TSS) and $\mathrm{SiO}_{2}$ according to NOAA GLERL standard operating procedures (Nalepa et al., 1996). Briefly, POC and PON were determined by filtering lake water through a pre-combusted $2.5 \mathrm{~cm} \mathrm{GF/F} \mathrm{filter} \mathrm{(Millipore).} \mathrm{Filters} \mathrm{were} \mathrm{frozen}$ in petri dishes immediately after filtration. Prior to analysis, filters were acidified with 3-5 drops of $10 \% \mathrm{HCl}$ and dried at $70{ }^{\circ} \mathrm{C}$ for 24 hours. Samples were analyzed with an Elemental Analyzer 1110 (CE Elantech). DOC samples were taken by vacuum filtering 40 ml lake water through a combusted GF/F filter and collecting filtrate in a clean beaker, under a Kontes bell jar. The filtrate was transferred into a sterile, polypropylene, sample-rinsed, $50 \mathrm{ml}$ test tube. The samples were frozen until analysis using a Shimadzu TOC 5000 high temperature combustion analyzer to determine non-purgeable organic carbon (NPOC, DOC operational definition). For total phosphorus (TP) $50 \mathrm{ml}$ lake water was poured into acid-cleaned glass test tubes and sealed with Teflon-lined caps. Samples were stored cold for less than 30 days until digested. For particulate phosphorus (PP), $200 \mathrm{ml}$ lake water were filtered through a $0.2 \mathrm{um}$ pore size $47 \mathrm{~mm}$ polycarbonate membrane filter (Millipore). Before digesting, $10 \mathrm{ml}$ of $5 \%$ persulfate solution and $50 \mathrm{ml}$ ultra-pure water were added. Total and particulate phosphorus samples were digested for 35 minutes at 2 atmospheres pressure with $10 \mathrm{ml} 5 \% \mathrm{~K}_{2}\left(\mathrm{SO}_{4}\right)_{2}$ solution. Samples were analyzed on a QuAAtro® segmented flow analyzer (Seal Analytical) using the ascorbic acid molybdenum blue method (Murphy and Riley, 1962).

DNA extraction and 16S rRNA gene sequencing. Duplicate nucleic acid extractions from different sections of the same $142 \mathrm{~mm}$ filter membrane were performed for each of the field samples using a modified AllPrep DNA/RNA/miRNA Universal kit protocol (Qiagen) 
(McCarthy et al., 2015). DNA was submitted to the Joint Genome Institute for amplicon sequencing targeting the V4 region of the $16 \mathrm{~S}$ rRNA gene (515F/806R universal primers) (Caporaso et al., 2012). Pooled libraries were sequenced on an Illumina MiSeq sequencer, using v2 chemistry 2x250 (500 cycles) paired-end reads. RTA v1.17.28 and MCS v2.2.0 software (Illumina, Inc.) were used to generate data. Illumina raw paired-end reads were filtered based on quality, and merged by JGI using their iTagger pipeline (Tremblay et al., 2015). This pipeline removes contaminants (PhiX control, sequencing library adapter dimers, human contaminants), trims PCR primers, trims the sequence reads based on quality, and merges paired end reads into single sequences. Raw and processed data are available on the Joint Genome Institute's genome data portal (http://genome.jgi.doe.gov/; Project IDs 1041195 and 1041198).

Sequence data analysis. The 88 samples $(24$ samples $* 2$ replicates $* 2=96,-8$ unsuccessful sequencing reactions; Table 1) were analyzed using Mothur version 1.34.3 using the MiSeq standard operating protocol (accessed on Dec 17, 2014) for sequence alignment and the generation of operational taxonomic unit (OTU, $97 \%$ sequence similarity) table (Schloss et al., 2009). Only bacterial sequences were retained (any reads classified as chloroplast, mitochondria, eukarya, archaea, and unknown were removed, ESM Table S1). For classification, we used a hybrid protocol using a freshwater-specific taxonomy (https://github.com/mcmahonuw/FWMFG) and the SILVA release 119 taxonomy (Quast et al., 2013) as previously described (Schmidt et al., 2016).

Further analyses were carried out in R version 3.2.1 using phyloseq (McMurdie and Holmes, 2013), vegan (Oksanen et al., 2013) as well as R functions developed by Michelle Berry (University of Michigan, personal communication; https://github.com/DenefLab/MicrobeMiseq). Full code and input files are available at https://github.com/DenefLab/LM13_DNA. We merged 
replicate samples by summing read counts prior to further analysis. All figures were generated using the ggplot2 R packages (Wickham, 2009), with additional editing in Illustrator (Adobe, Inc.).

For observed richness and Simpson's evenness, the OTU table was rarefied at 70,480 reads, a subsampling that allowed inclusion of all reads of the lowest sampling depth (certain samples contained up to $85 \%$ chloroplast sequences, which were removed during the Mothur analysis, ESMTable S1). To test for significant differences in richness and evenness based on season, station, filter fraction, or depth, we performed a Kruskall-Wallis test (kruskal.test; R Core Team., 2015) along with post-hoc tests to identify significant pairwise differences (kruskalmc in pgirmess R-package; Giraudoux, 2012), which were visualized using the multcompLetters function (multcompView R-package; Graves et al., 2012).

For comparisons of community composition across space and time, we first scaled all OTU read counts to the smallest merged library size (70,480 sequences) using the procedures described by (McMurdie and Holmes, 2014). We calculated the (abundance-weighted, i.e., binary = FALSE) Bray-Curtis dissimilarity and the OTU presence/absence-focused Sørensen dissimilarity (i.e., binary $=$ TRUE) between samples, and visualized these distances with a principal coordinates analysis (PCoA) ordination using the pcoa function (vegan). The PCoA was performed on both the full datasets after scaling (16,028 OTUs), as well as after limiting the OTU table to the most abundant taxa (> $0.1 \%$ on average after scaling, 139 OTUs, which represented $81+/-12 \%$ (standard deviation) of all sequence reads across all samples). We performed a nested permutational multivariate analysis of variance (PERMANOVA; Anderson, 2005) using the adonis function (vegan)in R to test if filter fraction, season, lake, station, depth, and day/night could significantly explain variation in the bacterial community composition. A 
Kruskall-Wallis test was performed as described above to compare whether median community dissimilarity was different among PA and FL fraction communities. We also performed a similar test to determine if community dissimilarity between surface communities at the different stations changed in function of season.

The 139 OTUs with average abundance $>0.1 \%$ across all samples were also classified to functional groups based on carbon and energy source. Functional class inferences from the taxonomic classification were made based on a literature search (papers describing isolates, genome sequences and gene expression, or substrate utilization assays combined with fluorescent in situ hybridization) as summarized in ESM Table S2.

We identified significant differences in the relative abundance of these 139 OTUs between the Muskegon Lake estuary and Lake Michigan, between seasons, fractions, and depth, each time while controlling for variation in all other factors. We used the negative binomial generalized linear model framework of the DESeq function in the DESeq2 R-package (Love et al., 2014; McMurdie and Holmes, 2014). P-values were adjusted for multiple testing through the Benjamini-Hochberg false discovery rate correction (Love et al., 2014).

To explore the correlation of between-sample biological variation and geochemical and physical data available for Lake Michigan samples, we carried out a bioenv analysis (vegan), an $\mathrm{R}$ implementation of the multivariate statistical method devised by Clarke and Ainsworth (Clark and Ainsworth, 1993). Separate analyses were performed for all samples, the FL fraction samples only, and the PA fraction samples only. The method calculates Euclidean dissimilarity matrices for each possible combination of environmental factors (from one factor to all factors) and a Bray-Curtis dissimilarity matrix for the biological data. Then, bioenv calculates Spearman rank correlations between the biological distance matrix and each environmental distance matrix 
and selects the subset of environmental factors with the highest Spearman correlation.

Significance levels were determined by comparing them to the distribution of maximum BIOENV correlations observed in 100 permutations obtained by randomizing row order in the biological data table.

\section{Results}

Spatiotemporal variation in environmental conditions.

The water column at the sampling stations (Fig. 1A-B) was isothermal in spring and stratified in summer and fall (Fig. 1C-F). Chla was consistently higher in the estuary than in Lake Michigan (Fig. 1C, G-I). Nearshore chla was higher than at the offshore station, except in summer, when a chlorophyll maximum was observed at $35-36 \mathrm{~m}$ below the water surface at the M110 offshore station (Fig. 1G-I). Within Lake Michigan stations, phosphorus levels were highest at the nearshore surface in spring, and lowest in the offshore deep in summer and fall (Table 1). POC was highest at the nearshore surface in spring. In the summer and fall, POC was higher in near and offshore surface waters and the offshore DCM than in offshore deep waters (Table 1).

\section{Bacterial richness and evenness}

The analyses of bacterial community richness and evenness were performed after clustering the small subunit ribosomal RNA sequences into operational taxonomic units (OTU) at $97 \%$ sequence identity (a proxy for bacterial species) and after rarefying the data at 70,480 reads (ESM Fig. S1). More OTUs were observed in spring compared to summer (Fig.2A: Kruskall-Wallis, $\mathrm{p}<0.05)$, and in Muskegon Lake and the nearshore Lake Michigan site relative 
to the offshore Lake Michigan site (Fig. 2B). Particle-associated fraction (PA) bacterial communities were similar in richness to free-living (FL) communities (Fig. 2C), and surface and deep communities did not significantly differ in richness either (Fig 2D). Evenness was low across all samples, indicating that relative to total observed richness in each sample, a small number of taxa predominated. Evenness was only significantly different between PA and FL fractions (Fig. 2E-H).

Spatiotemporal differences in abundance-weighted community composition.

When taking the relative abundance of taxa into account (Bray-Curtis dissimilarity), filter fraction and season were the strongest explanatory factors for differences in community composition (Fig. 3A, Table 2). Additional variation was explained by sampling station, primarily Muskegon Lake vs. Lake Michigan stations (Fig. 3B, Table 2). Depth influenced community composition less (Fig. 3B), and no significant differences were found between samples taken during the day and night (Table 2). The community composition patterns remained the same whether all 16,028 OTUs or only the 139 OTUs with relative abundance > $0.1 \%$ were included (Fig. S2A,C).

When comparing surface communities (deep samples excluded from comparison, as depth varied across the transect), the difference in community composition between spring estuary and nearshore samples was smaller than between estuary and offshore samples (Fig. 4; $p<0.05$, Kruskall-Wallis). In summer and fall, the difference in community composition between the estuary and both Lake Michigan stations was significantly larger than between the nearshore and offshore station (Fig. 4). 
In addition to being the strongest correlating factor with abundance-weighted community dissimilarity, the dissimilarity among PA communities (community turnover) was also significantly higher than among FL communities (Fig. 5A).

Bioenv analysis found no significant correlation between geochemical and physical parameters and biological data when both fractions were included, but did find different sets of factors resulting in the highest correlation between environmental and biological dissimilarities between samples (Table 3). When taking the best single environmental parameter correlating with FL biological dissimilarities and testing the correlation with PA biological dissimilarities and vice versa, correlation coefficients decreased $(\log (\operatorname{chl} l)$ vs PA: $r=0.38 ;$ T vs FL: $r=0.45)$.

\section{Difference in OTU presence between samples.}

When only considering the presence or absence of taxa (Sørensen dissimilarity), season and lake were the strongest explanatory factors for differences in community composition (Fig. S2B, Table 2). Filter fraction and depth explained additional, but less variation (Table 3). It was apparent that many OTUs were uniquely present in spring communities and that in summer and fall, Muskegon Lake harbored many unique OTUs compared to both Lake Michigan stations. While the patterns shift more than for the abundance-weighted PCoA, this analysis remained qualitatively similar whether all 16,028 OTUs or only the 139 OTUs with relative abundance > $0.1 \%$ were included (Fig. S2B,D).

Functional groups and taxa driving spatiotemporal gradients in BCC.

Instead of focusing strictly on taxonomic classifications, we classified the 139 OTUs with average relative abundance $>0.1 \%$ into functional groups using a literature search based on the 
assigned taxonomy. Functional groups were delineated based on carbon source (autotroph, heterotroph, mixotroph) and energy source (chemoorganotroph (organic energy source, including one carbon compounds (methylotroph)), chemolithotroph (inorganic energy source), phototroph (light, harvested with chla, bacteriochlorophyll, or bacteriorhodopsin) (ESM Table S2).

We first performed a DESeq analysis to identify OTUs with significantly different relative abundance between the fractions, which indicated partitioning of functional groups between the FL and PA fractions (Fig. 5B). For instance, we noted strong overrepresentation of autotrophic phototrophs (Cyanobacteria) and chemoorganoheterotrophs in the PA fraction, while chemoorganoheterotrophs that were inferred to complement their energy generation with bacteriorhodopsin-mediated phototrophy were overrepresented in the FL fraction. The latter pattern was driven in large part by the strong preference of Actinobacteria for the FL fraction (Fig. S3). Due to these large differences between the fractions at the functional group level, further analyses of differential abundance (Muskegon Lake estuary vs. Lake Michigan, between seasons, and between surface and deep) were performed for each fraction separately (Fig. 6). In line with the correlation values in the PERMANOVA analysis (Table 2), season and lake comparisons resulted in more OTUs with significantly different relative abundance and with larger effect sizes ( $\log _{2}$ fold ratio, $X$-axes in Fig. 6 ) than comparisons between surface and deep communities. In line with the large dissimilarity of spring relative to summer and fall communities, more differentially abundant OTUs and larger effect sizes were observed for summer to spring than fall to summer comparisons (Fig. 6). Specific taxa were annotated on Figure 6 based on (1) their overall relative abundance, (2) differential abundance patterns along the spatiotemporal gradient, and/or (3) differential abundances observed in a recent study along an estuary to pelagic gradient near Milwaukee, on the other side of Lake Michigan (Fig. 1A). 
The relative abundance of photoautotrophs was higher in summer and fall than in spring, and different taxa predominated in Muskegon Lake and Lake Michigan, though Synechococcus was the most abundant photoautotroph in both systems (Fig. 6). Only in the FL fraction did we observe taxa with higher relative abundance in the surface compared to the deep (note, deep was $\sim 10 \mathrm{~m}$ below the surface at the nearshore location, and $\sim 110 \mathrm{~m}$ at the offshore location, though Cyanobacteria were found at all depths throughout the system (Fig. 7, OTU3)).

Most of the 139 most abundant OTUs were chemoorganoheterotrophs and this functional group also contributed most of the differentially abundant OTUs, though for most comparisons there were a similar number of OTUs differentially abundant in both conditions (Fig. 6). Several Planctomyces OTUs had higher relative abundance in the estuary, though none were closely related to species able to perform the anaerobic oxidation of ammonium to $\mathrm{N}_{2}$ (Table $\mathrm{S} 2$ ). Different clades of Verrucomicrobia showed different patterns, with an OPB35 soil group OTU reaching higher relative abundances in the estuary, while a Verrucomicrobiaceae OTU reached higher relative abundances in Lake Michigan (Fig. 6, Fig. 7). Several of the most abundant chemoorganoheterotrophs reached their highest relative abundance in summer, including the most abundant Bacteroidetes taxon in the PA fraction (Aquir tribe, Fig. 6, Fig. 7).

Methylotrophs, which are chemoorganotrophs that oxidize one-carbon molecules as a source of energy (and potentially carbon), generally had higher relative abundance in the estuary than Lake Michigan. This was particularly true for mixotrophic methylotrophs (Fig. 6, Fig. 7), which also reached higher relative abundance in spring and fall compared to summer. The patterns varied between stations and fractions depending on the OTU, and generally we observed higher relative abundance of methylotrophs at the offshore location in Lake MI compared to the 
nearshore station (Fig. 7). The sole autotrophic methylotroph, LD19, gradually increased in relative abundance at both Lake Michigan stations from spring to fall (Fig. 6, 7).

A variety of chemoorganoheterotrophs that complement their energy generation with phototrophy using either bacteriorhodopsin or bacteriochlorophyll were present among the 139 most abundant OTUs. While many of them, particularly Actinobacteria acI lineages, had similar relative abundance throughout space and time, some specialization between the estuary and Lake Michigan and across time and depth was observed (Fig. 6). LD12, a sister clade to one of the most abundant marine bacterial clades (SAR11), had higher relative abundance in Lake Michigan than Muskegon Lake, though this difference was not statistically significant as autumnal relative abundances were similarly high across all stations. Chloroflexi CL500-11 became increasingly abundant in deep offshore waters (Fig. 6,7). This increase coincided with an increase of the sole OTU that we could confidently assign as a chemolithoautotroph, Nitrosospira, which is an autotrophic ammonium oxidizer.

Finally, a series of OTUs were assigned to the most versatile functional groups, which combined all three types of energy generation. The most abundant one, a Limnohabitans OTU (tribe Lhab-A1), showed limited differential abundance across space and time (Fig. 6). However, other OTUs with the same taxonomic assignment showed more station-specific dynamics, such as OTU105979, which was only found in spring in the estuary, when it contributed $10 \%$ of all sequences (Fig. 7). We also observed this divergence of spatiotemporal dynamics among related Polynucleobacter OTUs (Fig. 7).

\section{Discussion}


The Muskegon transect of Lake Michigan is one of the most extensively and longest studied areas of the Laurentian Great Lakes. Most studies have focused on fish and eukaryotic plankton community composition along this estuary to pelagic gradient (Fahnenstiel et al., 2010; Gillett and Steinman, 2011; Madenjian et al., 2002). Despite the importance of bacterial populations in biogeochemical cycling and potential importance in food web interactions with higher trophic levels (Scavia and Laird, 1987), this study is the first report on the drivers of bacterial diversity and community composition along this transect. Not unexpectedly, seasonal changes in environmental conditions are a main driver of both species richness and differences in bacterial compositions, with more diverse and distinct communities, based on both species presence/absence and relative abundance of shared taxa, existing in the highly productive estuary compared to the Lake Michigan communities. Our study also highlights the distinct bacterial communities associated with particulate matter relative to free-living bacteria, which were also observed in previous studies in western Lake Erie (Mou et al. 2013) as well as smaller freshwater lake and marine systems (Allgaier and Grossart, 2006; Bižić - Ionescu et al., 2014; Rösel and Grossart, 2012; Schmidt et al., 2016). Particle-associated (PA) fraction bacterial populations are particularly interesting along the Muskegon transect as they are more diverse, highly distinct in phylogenetic and functional group composition, and more variable over time and space than freeliving (FL) communities. As the PA fraction likely contains more eukaryotic cells relative to bacterial cells than the FL fraction, as evidenced by the higher fraction of chloroplast sequences removed (ESM Table S1), it is possible that interactions with eukaryotic phytoplankton and microzooplankton drive these patterns. Future integration with data gathered in parallel to our efforts will allow us to explore this hypothesis. 
More broadly, despite the fact that the Laurentian Great Lakes contain approximately one fifth of the world's surface freshwater, high-throughput sequencing to survey bacterial community composition has only recently been applied to the Great Lakes. Currently multiple surveys are being undertaken, with first results highlighting divergent communities across time, depth, and space in the pelagic environment of the Great Lakes ( Beall et al., 2016; Fisher et al., 2015; Mou et al., 2013; Newton and McLellan, 2015; Rozmarynowycz, 2014; Wilhelm et al., 2014). Our study, together with recently published studies on a similar transect near Milwaukee (Fisher et al., 2015; Newton and McLellan, 2015) add insights into the bacterial communities in the more productive regions of the lakes, specifically nearshore and estuary regions. A better understanding of compositional differences between these regions of the Great Lakes is a stepping stone towards studies that investigate links between compositional changes and shifts in bacterially mediated functions (Nemergut et al., 2014). Better understanding of drivers of compositional and functional changes in nearshore and estuary regions in particular is of interest as these regions have become of increased importance in sustaining Great Lakes food webs since the invasion of dreissenid mussels (Vanderploeg et al., 2010).

Our observations of diversity and BCC trends along the Muskegon transect partially corroborate the studies on the Milwaukee transect (Fisher et al., 2015; Newton and McLellan, 2015),. They extend these first studies by (1) resolving the different dynamics in the FL and PA fractions, (2) including seasonal and depth profile analyses, and (3) focusing on geochemically important functional groups. The distinct composition of bacterial communities in the estuary and pelagic environments are likely due to the difference in organic matter concentrations and compositions along estuary to pelagic gradients (Dila and Biddanda, 2015; Marko et al., 2013). Previous experimental studies have shown that resource differences lead to differences in 
bacterial community compositions (Jones et al., 2009; Kritzberg et al., 2006). The estuary is also marked by substantially higher water temperatures during summer and fall (Fig. 1C-F), which is another known factor shaping bacterial community composition (Hall et al., 2008; Kosten et al., 2012; Scheibner et al., 2014), and which our bioenv analysis identified among the subset of highest correlating environmental factors with community composition in both FL and PA fractions. In addition, nutrient levels differ between oligotrophic Lake Michigan and meso- to eutrophic Muskegon Lake, which can affect bacterial community composition and diversity (Jankowski et al., 2014; Lauro et al., 2009; Schmidt et al., 2016; Yannarell et al., 2003). The above factors, as well as increased mass effects from the Muskegon River and urban runoff are likely driving factors for the BCC differences along this spatial gradient as suggested for the Milwaukee transect study (Newton and McLellan, 2015).

While these general trends of richness and community composition are comparable to the Milwaukee results, a more detailed analysis of the taxa that show preference between Lake Michigan and the estuary does reveal several differences. Whereas the acI-A lineage was shown not to show differential representation between the Milwaukee estuary and Lake Michigan, subgroups of this lineage do show strong preferences between the Muskegon estuary and Lake Michigan in our study. Similarly, we showed that specific OTUs within the acI-B lineage either show no or strong preference for Lake Michigan, whereas the acI-B lineage taken as a whole was indicated to show preference for Lake Michigan by Newton (Newton and McLellan, 2015). It has to be noted that a more resolved analysis by Newton (oligotyping) did reveal similar divergences in habitat specialization. LD12, which showed the strongest preference of all taxonomic groups in the Milwaukee study (a 12-fold preference for Lake Michigan), did not show a significant preference in our case. In spring and summer, LD12 was indeed almost 
exclusively found in Lake Michigan (representing up to $25 \%$ of all sequencing reads in offshore surface waters), yet in fall levels at all stations were similar $(\sim 10 \%$ at the surface and $\sim 5 \%$ in the deep). Our study thus shows that seasonality has strong effects on habitat preference patterns across this estuary to pelagic gradient. Similar to the conclusion from Newton and McLellan's oligotyping work, which resolves sequence differences down to the single nucleotide level, our work shows that even at the level of OTUs (which bundles sequences up to $3 \%$ divergent from each other) that were assigned the same or very similar taxonomy (e.g., Pnec, Lhab), highly distinct patterns in spatial and temporal relative abundance dynamics can be seen. Whether these closely related taxa carry out similar functions or may contribute differently to bacterially mediated processes remains to be determined.

The compositions of PA bacterial communities are more variable across seasons and spatial gradients than FL communities, which is similar to previous reports in small inland lakes (Rösel and Grossart, 2012; Schmidt et al., 2016). Particles in aquatic environments are heterogeneous in nature by being comprised of eukaryotic phytoplankton, small zooplankton, excretes of zooplankton, detritus, and other organic particulate matter including allochthonous materials from rivers (Anadón et al., 2002; Turner, 2015). The concentration and the composition of particles are known to vary across time and locations (Turner, 2015). Substrates for free-living organisms are primarily different types of dissolved organic matter (DOM), and their composition and concentration also changes through time and locations (Crump et al., 2003; Reche et al., 1998), which likely contributes to the spatiotemporal patterns in free-living fractions. Our data do not allow us to identify the cause for this pattern, though correlation with chl $a$ levels, which only varied moderately across space and time in Lake Michigan is supportive of the role of algal-derived organic matter as a shaping force. In contrast, the best subset of 
environmental factors correlating with PA community turnover included total suspended solids, implicating particulate matter concentrations and possibly its composition in Lake Michigan. The Milwaukee transect BCC combined both size fractions in one and thus their patterns were driven by the more numerically dominant FL fraction bacterial populations. Hence, they observed similar patterns as we observed for the FL fraction (i.e., several abundant populations occurring throughout the transect) (Newton and McLellan, 2015).

While the abundance of bacterial populations associated with particles are typically small relative to FL bacteria (Azam et al., 1983; Bižić - Ionescu et al., 2014; Ghiglione et al., 2007), PA bacterial populations can be metabolically highly active and thus play significant roles in decomposition and remineralization of particulate organic matter (Ghiglione et al., 2007; Grossart et al., 2007). The higher variability among PA than FL bacterial composition, differences in phylogenetic and functional group composition of FL and PA fractions, and differences between the environmental factors that correlate with changes in community composition in the fractions suggest different drivers of community assembly between FL and PA fractions. Further work is needed to link differences in process levels across the system to community turnover in these fractions and identify which communities underpin changes in ecosystem functioning across the transect and over time.

While depth overall is less of a driver of community dissimilarity, very distinct taxa were found at the offshore station in particular. Of particular interest is the high relative abundance of Chloroflexi CL500-11 (OTU21), the genomic analysis of which has recently suggested its importance in the remineralization of nitrogen-rich DOM (Denef et al., 2016), and the cooccurrence of an autotrophic ammonia oxidizer (Nitrosospira, OTU119). Considering the gradually increasing levels of nitrate in the upper Great Lakes (Dove and Chapra, 2015), 
interactions between the abundant Chloroflexi and Nitrosospira will be of interest for future studies. Recent studies in the Great Lakes have documented higher levels of ammonium oxidation in the hypolimnion compared to the epilimnion (Small et al., 2013), which is in line with our observed absence of ammonium oxidizers in the epilimnion. In addition, ammoniumoxidizing archaea (AOA) were more prevalent in the hypolimnion of Lake Superior, while ammonium oxidizing bacteria (AOB), particularly Nitrosospira, predominated in Lake Erie (Mukherjee et al., 2016). As we focused on the bacterial communities in this study, we cannot determine whether AOA are prevalent in Lake Michigan, but the same AOB taxa predominating in Lake Erie appear to be present in Lake Michigan.

In our study, the highest bacterial diversity was observed in spring compared to summer when productivity (assessed based on system-wide chl $a$ concentrations) peaks. Recent studies by others have found a negative relationship between productivity and bacterial diversity, where winter bacterial populations under ice were more diverse than in summer (Ghiglione and Murray, 2012; Grzymski et al., 2012). The explanation provided for this phenomenon was that resource diversity may be high in winter while resources are relatively homogeneous in summer productive months. This hypothesis of low resource diversity in summer productive month was supported by a recent study (Becker et al., 2014). In contrast, we found that along the transect, the highest diversity was observed in the productive estuary relative to the nearshore and nutrient scarce offshore environment in summer and fall. The fact that the estuary was not just productive but also had high resource diversity by receiving allochthonous organic matter may explain this contradictory result. The estuary also has the highest stochastic mass effects as it experiences a high influx of bacteria from terrestrial origins. 
Previous process level measurements have indicated that the Muskegon Lake estuary and near shore of Lake Michigan serve as carbon sinks while the offshore pelagic environment serves as carbon source with respiration exceeding gross production in the surface waters during summer (Weinke et al., 2014). Dominance of bacterial heterotrophs in pelagic surface communities in summer and increased presence of bacterial primary producers in the estuary and nearshore surface waters are in line with these findings. Our study adds insight into the potential bacterial roles in carbon flux when the deeper parts of the water column are taken into account. First, while chla levels were low throughout the water column at the offshore station in spring, a chlorophyll maximum formed in summer ( $\sim 35 \mathrm{~m}$ below surface) and thus total water column primary production could exceed respiration if this zone is taken into account. Second, when other seasons are considered, a previous study suggested net carbon emissions from Muskegon Lake in winter months (Ogdahl et al., 2010). Indeed, few cyanobacterial sequences were identified in spring, though several OTUs were classified as taxa with known mixotrophic carbon source usage, which may affect the carbon flux. As our analyses were restricted to the bacterial community, no information was gained on eukaryotic phytoplankton, which based on chla levels in spring were likely abundantly present. Previous studies identified nearshore diatom and cryptophyte blooms in spring (Millie et al., 2002), which would explain the high levels of chla despite cyanobacterial absence in our data.

The spatiotemporal shifts in bacterial community composition, and of the inferred functional groups the differentially represented OTUs belong to, suggest that bacteria-driven biogeochemical processes differ between FL and PA fraction communities, seasons, depth, and along the estuary to pelagic gradient. Yet, the delineated functional groups were very broad, and interpretations of the impact of the observed differences in bacterial community composition on 
overall biogeochemical cycling are limited by the limited correlation between phylogeny and functional traits, such as the ability to degrade specific classes of organic matter, among bacteria (Martiny et al., 2015). Future studies that focus on genome reconstruction and analysis of in situ gene expression patterns of important Great Lakes bacterial populations, as recently performed for CL500-11 Chloroflexi (Denef et al., 2016) and ongoing work focused on substrate uptake assays and obtaining bacterial isolates (Salcher et al., 2013; Salcher et al., 2015), will provide much needed insights into functional repercussions of the observed differences in community composition. Another limitation of this study is that the observed spatiotemporal trends in bacterial communities cannot be explained solely by heterogeneity in geochemical and physical factors. Predation by nanoflagellates (Callieri et al., 2002; Christaki et al., 2001; Duarte et al., 2005; Šimek and Chrzanowski, 1992) and population control by parasitic viruses (Brum et al., 2015; Payet and Suttle, 2008; Pearce et al., 2007) also plays a critical role in shaping bacterial communities, but such predation was not assessed in this study.

\section{Conclusion}

Human activities continue to affect the Great Lakes basin, mainly through eutrophication of estuaries and nearshore regions and introduction of invasive mussels that have deplete resources in mid depth offshore regions. We know very little about how these disturbances affect Great Lakes bacterial communities and their impact on ecosystem processes. While no comparable pre-invasion data are available, dreissenid mussels have likely altered bacterial communities directly through selective filter feeding (Cotner et al., 1995; Findlay et al., 1998; Frischer et al., 2000; Vanderploeg et al., 2001) and indirectly by affecting concentrations and compositions of primary producers, organic matter, and consumers (Higgins and Zanden, 2010). 
Global climate change can alter the timing and depth of the thermocline (King et al., 1997) and the introduction of new invasive species such as Asian Carp (Cuddington et al., 2014; Jerde et al., 2013) will continue to alter Great Lakes bacterial communities. Our study has outlined how functional groups are partitioned across small (PA vs. FL) and larger scale (spatial and temporal) gradients along one of the best-monitored research transects in the Great Lakes. Integrating these insights with data on other trophic levels obtained simultaneously with our data will help increase understanding of the role of these bacterial communities in ecosystem function. Together with efforts elsewhere in the Great Lakes, we can now establish an understanding of the current baseline of bacterial community composition and functioning, and through experimentation and continued monitoring we can infer how these communities and the ecosystem services they provide may change in the future.

\section{Acknowledgments.}

VJD was supported by the Community Sequencing Program (U.S. Department of Energy Joint Genome Institute, a DOE Office of Science User Facility, supported under Contract No. DEAC02-05CH11231). We are grateful to research staff at the NOAA Great Lakes Environmental Research Laboratory (Ann Arbor, MI) and the crew of the R/V Laurentian for ship time and fieldwork support. We would like to thank Marian Schmidt for her help with field sampling, Marian Schmidt and Michelle Berry for providing R code, and current members of the Denef laboratory as well as the anonymous reviewers for input on previous versions of this manuscript.

\section{References}


Abelho, M., 2001. From litterfall to breakdown in streams: a review. Sci. World J. 1, 656-680. Allan, J.D., McIntyre, P.B., Smith, S.D., Halpern, B.S., Boyer, G.L., Buchsbaum, A., Burton, G., Campbell, L.M., Chadderton, W.L., Ciborowski, J.J., 2013. Joint analysis of stressors and ecosystem services to enhance restoration effectiveness. Proc. Natl. Acad. Sci. USA 110, 372377.

Allgaier, M., Grossart, H.-P., 2006. Seasonal dynamics and phylogenetic diversity of free-living and particle-associated bacterial communities in four lakes in northeastern Germany. Aquat. Microb. Ecol. 45, 115-128.

Anadón, R., Alvarez-Marqués, F., Fernández, E., Varela, M., Zapata, M., Gasol, J.M., Vaqué, D., 2002. Vertical biogenic particle flux during austral summer in the Antarctic Peninsula area. Deep Sea Res. Pt. II 49, 883-901.

Anderson, M. J. 2005. Permutational multivariate analysis of variance. Aust. Ecol. 26, 32-46.

Azam, F., Fenchel, T., Field, J.G., Gray, J., Meyer-Reil, L., Thingstad, F., 1983. The ecological role of water-column microbes in the sea. Mar. Ecol. Prog. Ser. 10, 257-263.

Beall, B.F.N., Twiss, M.R., Smith, D.E., Oyserman, B.O., Rozmarynowycz, M.J., Binding, C.E., et al., 2016. Ice cover extent drives phytoplankton and bacterial community structure in a large north-temperate lake: implications for a warming climate. Environ Microbiol 18: 17041719.

Becker, J.W., Berube, P.M., Follett, C.L., Waterbury, J.B., Chisholm, S.W., DeLong, E.F., Repeta, D.J., 2014. Closely related phytoplankton species produce similar suites of dissolved organic matter. Front. Microbiol. 5, 111.

Bird, D., Kalff, J., 1984. Empirical relationships between bacterial abundance and chlorophyll concentration in fresh and marine waters. Can. J. Fish. Aquat. Sci. 41, 1015-1023. 
Bižić-Ionescu, M., Zeder, M., Ionescu, D., Orlić, S., Fuchs, B.M., Grossart, H.P., Amann, R., 2014. Comparison of bacterial communities on limnic versus coastal marine particles reveals profound differences in colonization. Environ. Microbiol. 17(10), 3500-3514

Brum, J.R., Hurwitz, B.L., Schofield, O., Ducklow, H.W., Sullivan, M.B., 2015. Seasonal time bombs: dominant temperate viruses affect Southern Ocean microbial dynamics. ISME J., in press.

Callieri, C., Karjalainen, S.M., Passoni, S., 2002. Grazing by ciliates and heterotrophic nanoflagellates on picocyanobacteria in Lago Maggiore, Italy. J. Plankton Res. 24, 785-796.

Caporaso, J.G., Lauber, C.L., Walters, W.A., Berg-Lyons, D., Huntley, J., Fierer, N., Owens, S.M., Betley, J., Fraser, L., Bauer, M., 2012. Ultra-high-throughput microbial community analysis on the Illumina HiSeq and MiSeq platforms. ISME J. 6, 1621-1624.

Christaki, U., Giannakourou, A., Van Wambeke, F., Grégori, G., 2001. Nanoflagellate predation on auto-and heterotrophic picoplankton in the oligotrophic Mediterranean Sea. J. Plankton Res. 23, 1297-1310.

Clarke, K.R. and Ainsworth, M., 1993. A method of linking multivariate community. Mar. Ecol. Prog. Ser., 92, 205-219.

Cole, J.J., Findlay, S., Pace, M.L., 1988. Bacterial production in fresh and saltwater ecosystems: a cross-system overview. Mar. Ecol. Prog. Ser. 43, 1-10.

Cole, J.J., Prairie, Y.T., Caraco, N.F., McDowell, W.H., Tranvik, L.J., Striegl, R.G., Duarte, C.M., Kortelainen, P., Downing, J.A., Middelburg, J.J., 2007. Plumbing the global carbon cycle: integrating inland waters into the terrestrial carbon budget. Ecosystems 10, 172-185.

Cotner, J.B., Biddanda, B.A., 2002. Small players, large role: microbial influence on biogeochemical processes in pelagic aquatic ecosystems. Ecosystems 5, 105-121. 
Cotner, J.B., Gardner, W.S., Johnson, J.R., Sada, R.H., Cavaletto, J.F., Heath, R.T., 1995. Effects of zebra mussels (Dreissena polymorpha) on bacterioplankton: Evidence for both sizeselective consumption and growth stimulation. J. Great Lakes Res. 21, 517-528.

Crump, B.C., Kling, G.W., Bahr, M., Hobbie, J.E., 2003. Bacterioplankton community shifts in an arctic lake correlate with seasonal changes in organic matter source. Appl. Environ. Microbiol. 69, 2253-2268.

Cuddington, K., Currie, W., Koops, M., 2014. Could an Asian carp population establish in the Great Lakes from a small introduction? Biol. Invasions 16, 903-917.

DeLong, E.F., Preston, C.M., Mincer, T., Rich, V., Hallam, S.J., Frigaard, N.-U., Martinez, A., Sullivan, M.B., Edwards, R., Brito, B.R., 2006. Community genomics among stratified microbial assemblages in the ocean's interior. Science 311, 496-503.

Denef, V.J., Mueller, R.S., Chiang, E., Liebig, J.R., Vanderploeg, H.A., 2016. Chloroflexi CL500-11 populations that predominate deep lake hypolimnion bacterioplankton rely on nitrogen-rich DOM metabolism and C1 compound oxidation. Appl. Environ. Microbiol., 82(5), 1423-1432.

Dila, D.K., Biddanda, B.A., 2015. From land to lake: Contrasting microbial processes across a Great Lakes gradient of organic carbon and inorganic nutrient inventories. J. Great Lakes Res. $41,75-85$.

Dove, A., Chapra, S.C., 2015. Long-term trends of nutrients and trophic response variables for the Great Lakes. Limnol. Oceanogr. 60, 696-721.

Duarte, C.M., Agustí, S., Vaqué, D., Agawin, N.S., Felipe, J., Casamayor, E.O., Gasol, J.M., 2005. Experimental test of bacteria-phytoplankton coupling in the Southern Ocean. Limnol. Oceanogr. 50, 1844-1854. 
Fagerland, M.W., Sandvik, L., 2009. Performance of five two-sample location tests for skewed distributions with unequal variances. Contemp. Clin. Trials 30, 490-496.

Fahnenstiel, G., Pothoven, S., Vanderploeg, H., Klarer, D., Nalepa, T., Scavia, D., 2010. Recent changes in primary production and phytoplankton in the offshore region of southeastern Lake Michigan. J. Great Lakes Res. 36, 20-29.

Falkowski, P.G., Fenchel, T., Delong, E.F., 2008. The microbial engines that drive Earth's biogeochemical cycles. Science 320, 1034-1039.

Findlay, S., Pace, M., Fischer, D., 1998. Response of heterotrophic planktonic bacteria to the zebra mussel invasion of the tidal freshwater Hudson River. Microb. Ecol. 36, 131-140.

Fisher, J.C., Newton, R.J., Dila, D.K., McLellan, S.L., 2015. Urban microbial ecology of a freshwater estuary of Lake Michigan. Elementa: Science of the Anthropocene 3, 000064.

Frischer, M.E., Nierzwicki-Bauer, S.A., Parsons, R.H., Vathanodorn, K., Waitkus, K.R., 2000. Interactions between zebra mussels (Dreissena polymorpha) and microbial communities. Can. J. Fish. Aquat. Sci. 57, 591-599.

Ghiglione, J., Mevel, G., Pujo-Pay, M., Mousseau, L., Lebaron, P., Goutx, M., 2007. Diel and seasonal variations in abundance, activity, and community structure of particle-attached and free-living bacteria in NW Mediterranean Sea. Microb. Ecol. 54, 217-231.

Ghiglione, J., Murray, A., 2012. Pronounced summer to winter differences and higher wintertime richness in coastal Antarctic marine bacterioplankton. Environ. Microbiol. 14, 617-629.

Gillett, N.D., Steinman, A.D., 2011. An analysis of long-term phytoplankton dynamics in Muskegon Lake, a Great Lakes Area of Concern. J. Great Lakes Res. 37, 335-342.

Giraudoux, P. 2012. pgirmess: Data Analysis in Ecology. R Package Version 1.5. 9. 
Graves, S., Piepho, H. P., Selzer, L., and Dorai-Jai, S. 2012. MultcompView: Visualizations of Paired Comparisons. R Package Version 0.1-5. Available online at: http://CRAN.Rproject.org/package $=$ multcompView

Grossart, H.-P., Tang, K.W., Kiørboe, T., Ploug, H., 2007. Comparison of cell-specific activity between free-living and attached bacteria using isolates and natural assemblages. FEMS Microbiol. Lett. 266, 194-200.

Grossart, H.P., 2010. Ecological consequences of bacterioplankton lifestyles: changes in concepts are needed. Environ. Microbiol. Rep. 2, 706-714.

Grzymski, J.J., Riesenfeld, C.S., Williams, T.J., Dussaq, A.M., Ducklow, H., Erickson, M., Cavicchioli, R., Murray, A.E., 2012. A metagenomic assessment of winter and summer bacterioplankton from Antarctica Peninsula coastal surface waters. ISME J. 6, 1901-1915.

Hall, E.K., Neuhauser, C., Cotner, J.B., 2008. Toward a mechanistic understanding of how natural bacterial communities respond to changes in temperature in aquatic ecosystems. ISME J. 2, 471-481.

Higgins, S., Zanden, M.V., 2010. What a difference a species makes: a meta-analysis of dreissenid mussel impacts on freshwater ecosystems. Ecol. Monogr. 80, 179-196.

Jankowski, K., Schindler, D.E., Horner-Devine, M.C., 2014. Resource availability and spatial heterogeneity control bacterial community response to nutrient enrichment in lakes. PLoS One 9, e86991.

Jerde, C.L., Chadderton, W.L., Mahon, A.R., Renshaw, M.A., Corush, J., Budny, M.L., Mysorekar, S., Lodge, D.M., 2013. Detection of Asian carp DNA as part of a Great Lakes basin-wide surveillance program. Can. J. Fish. Aquat. Sci. 70, 522-526. 
Johengen, T.H., Biddanda, B.A., Cotner, J.B., 2008. Stimulation of Lake Michigan plankton metabolism by sediment resuspension and river runoff. J. Great Lakes Res. 34, 213-227.

Jones, S.E., Newton, R.J., McMahon, K.D., 2009. Evidence for structuring of bacterial community composition by organic carbon source in temperate lakes. Environ. Microbiol. 11, 2463-2472.

King, J.R., Shuter, B.J., Zimmerman, A.P., 1997. The response of the thermal stratification of South Bay (Lake Huron) to climatic variability. Can. J. Fish. Aquat. Sci. 54, 1873-1882.

Kosten, S., Huszar, V.L., Bécares, E., Costa, L.S., Donk, E., Hansson, L.A., Jeppesen, E., Kruk, C., Lacerot, G., Mazzeo, N., 2012. Warmer climates boost cyanobacterial dominance in shallow lakes. Global Change Biol. 18, 118-126.

Kritzberg, E.S., Langenheder, S., Lindström, E.S., 2006. Influence of dissolved organic matter source on lake bacterioplankton structure and function-implications for seasonal dynamics of community composition. FEMS Microbiol. Ecol. 56, 406-417.

Larson, J.H., Trebitz, A.S., Steinman, A.D., Wiley, M.J., Mazur, M.C., Pebbles, V., Braun, H.A., Seelbach, P.W., 2013. Great Lakes rivermouth ecosystems: scientific synthesis and management implications. J. Great Lakes Res. 39, 513-524.

Lauro, F.M., McDougald, D., Thomas, T., Williams, T.J., Egan, S., Rice, S., DeMaere, M.Z., Ting, L., Ertan, H., Johnson, J., 2009. The genomic basis of trophic strategy in marine bacteria. Proc. Natl. Acad. Sci. USA 106, 15527-15533.

Lindström, E.S., Langenheder, S., 2012. Local and regional factors influencing bacterial community assembly. Environ. Microbiol. Rep. 4, 1-9.

Love, M. I., Huber, W., and Anders, S. 2014. Moderated estimation of fold change and dispersion for RNA-seq data with DESeq2. Genome Biol. 15, 550. 
Madenjian, C.P., Fahnenstiel, G.L., Johengen, T.H., Nalepa, T.F., Vanderploeg, H.A., Fleischer, G.W., Schneeberger, P.J., Benjamin, D.M., Smith, E.B., Bence, J.R., 2002. Dynamics of the Lake Michigan food web, 1970 2000. Can. J. Fish. Aquat. Sci. 59, 736-753.

Marko, K.M., Rutherford, E.S., Eadie, B.J., Johengen, T.H., Lansing, M.B., 2013. Delivery of nutrients and seston from the Muskegon River Watershed to near shore Lake Michigan. J. Great Lakes Res. 39, 672-681.

Martiny, J.B., Jones, S.E., Lennon, J.T., Martiny, A.C., 2015. Microbiomes in light of traits: A phylogenetic perspective. Science 350, aac9323.

McCarthy, A., Chiang, E., Schmidt, M.L., Denef, V.J., 2015. RNA Preservation Agents and Nucleic Acid Extraction Method Bias Perceived Bacterial Community Composition. PLoS One 10, e0121659.

McMurdie, P.J., Holmes, S., 2013. phyloseq: an R package for reproducible interactive analysis and graphics of microbiome census data. PLoS One 8, e61217.

McMurdie, P. J., and Holmes, S. 2014. Waste not, want not: why rarefying microbiome data is inadmissible. PLoS Comput. Biol. 10:e1003531.

Millie, D.F., Fahnenstiel, G.L., Carrick, H.J., Lohrenz, S.E., Schofield, O.M., 2002. Phytoplankton pigments in coastal lake michigan: distributions during the spring isothermal period and relation with episodic sediment resuspension1. J. Phycol. 38, 639-648.

Morán, X.A.G., Gasol, J.M., Pedrós-Alió, C., Estrada, M., 2001. Dissolved and particulate primary production and bacterial production in offshore Antarctic waters during austral summer: coupled or uncoupled? Mar. Ecol. Prog. Ser. 222, 25-39. 
Mou, X., Jacob, J., Lu, X., Robbins, S., Sun, S., Ortiz, J.D., 2013. Diversity and distribution of free-living and particle-associated bacterioplankton in Sandusky Bay and adjacent waters of Lake Erie Western Basin. J. Great Lakes Res. 39, 352-357.

Mukherjee, M., Ray, A., Post, A.F., McKay, R.M., Bullerjahn, G.S. Identification, enumeration and diversity of nitrifying planktonic archaea and bacteria in trophic end members of the Laurentian Great Lakes. J. Great Lakes Res., in press.

Murphy, J., Riley, J.P. 1962. A modified single solution method for the determination of phosphate in natural waters. Anal Chim Acta 27, 31-36.

Nalepa, T., Fahnenstiel, G.L., McCormick, M., Johengen, T.H., Lang, G., Cavaletto, J.F., Goudy, G., 1996. Physical and chemical variables of Saginaw Bay, Lake Huron in 1991-93. NOAA Tech. Mem. ERL GLERL.

Nemergut, D.R., Shade, A. and Violle, C., 2014. When, where and how does microbial community composition matter?. Frontiers in microbiology, 5, 497.

Newton, R.J., Jones, S.E., Eiler, A., McMahon, K.D., Bertilsson, S., 2011. A guide to the natural history of freshwater lake bacteria. Microbiol. Mol. Biol. Rev. 75, 14-49.

Newton, R.J., McLellan, S.L., 2015. A unique assemblage of cosmopolitan freshwater bacteria and higher community diversity differentiate an urbanized estuary from oligotrophic Lake Michigan. Front. Microbiol. 6, 1028.

Obernosterer, I., Christaki, U., Lefèvre, D., Catala, P., Van Wambeke, F., Lebaron, P., 2008. Rapid bacterial mineralization of organic carbon produced during a phytoplankton bloom induced by natural iron fertilization in the Southern Ocean. Deep Sea Res. Pt. II 55, 777-789.

Ogdahl, M.E., Lougheed, V.L., Stevenson, R.J., Steinman, A.D., 2010. Influences of multi-scale habitat on metabolism in a coastal Great Lakes watershed. Ecosystems 13, 222-238. 
Oksanen, J., Blanchet, F. G., Kindt, R., Legendre, P., Minchin, P. R., OHara, R. B., et al. 2013. Vegan: Community Ecology Package. R Package Version 2.0-10.

Parks, D.H., Tyson, G.W., Hugenholtz, P., Beiko, R.G., 2014. STAMP: statistical analysis of taxonomic and functional profiles. Bioinformatics 30, 3123-3124.

Payet, J.P., Suttle, C.A., 2008. Physical and biological correlates of virus dynamics in the southern Beaufort Sea and Amundsen Gulf. J. Mar. Syst. 74, 933-945.

Pearce, I., Davidson, A.T., Bell, E.M., Wright, S., 2007. Seasonal changes in the concentration and metabolic activity of bacteria and viruses at an Antarctic coastal site. Aquat. Microb. Ecol. 47, 11-23.

Pothoven, S.A., Fahnenstiel, G.L., 2014. Spatial and temporal trends in zooplankton assemblages along a nearshore to offshore transect in southeastern Lake Michigan from 2007 to 2012. J. Great Lakes Res. 41, 95-103.

Quast, C., Pruesse, E., Yilmaz, P., Gerken, J., Schweer, T., Yarza, P., Peplies, J., Glöckner, F.O., 2013. The SILVA ribosomal RNA gene database project: improved data processing and webbased tools. Nucleic Acids Res. 41, D590-D596.

R Core Team. 2015. R: A Language and Environment for Statistical Computing. Available online at: https://www.R-project.org/

Reche, I., Pace, M., Cole, J., 1998. Interactions of photobleaching and inorganic nutrients in determining bacterial growth on colored dissolved organic carbon. Microb. Ecol. 36, 270-280.

Rösel, S., Grossart, H.-P., 2012. Contrasting dynamics in activity and community composition of free-living and particle-associated bacteria in spring. Aquat. Microb. Ecol. 66, 169-181.

Rozmarynowycz, M., 2014. Spatio-Temporal Distribution of Microbial Communities in the Laurentian Great Lakes. Doctoral Dissertation Bowling Green State University. 
Ruxton, G.D., 2006. The unequal variance t-test is an underused alternative to Student's t-test and the Mann-Whitney U test. Behav. Ecol. 17, 688-690.

Salcher, M. M., Posch, T., and Pernthaler, J. 2013. In situ substrate preferences of abundant bacterioplankton populations in a prealpine freshwater lake. ISME J. 7, 896-907.

Salcher, M. M., Neuenschwander, S. M., Posch, T., and Pernthaler, J. (2015). The ecology of pelagic freshwater methylotrophs assessed by a high-resolution monitoring and isolation campaign. ISME J. 9, 2442-2453

Scavia, D., Laird, G.A., 1987. Bacterioplankton in Lake Michigan: Dynamics, controls, and significance to carbon flux1. Limnol. Oceanogr. 32, 1017-1033.

Scheibner, M., Dörge, P., Biermann, A., Sommer, U., Hoppe, H.G., Jürgens, K., 2014. Impact of warming on phyto- bacterioplankton coupling and bacterial community composition in experimental mesocosms. Environ. Microbiol. 16, 718-733.

Schloss, P.D., Westcott, S.L., Ryabin, T., Hall, J.R., Hartmann, M., Hollister, E.B., Lesniewski, R.A., Oakley, B.B., Parks, D.H., Robinson, C.J. and Sahl, J.W. 2009. Introducing mothur: Open-source, platform-independent, community-supported software for describing and comparing microbial communities. Appl. Environ. Microbiol., 75(23):7537-41.

Schloss, P.D., Westcott, S.L., 2011. Assessing and improving methods used in operational taxonomic unit-based approaches for 16S rRNA gene sequence analysis. Appl. Environ. Microbiol. 77, 3219-3226.

Schmidt, M.L., White, J.D., Denef, V.J., 2016. Phylogenetic conservation of freshwater lake habitat preference varies between abundant bacterioplankton phyla. Environ. Microbiol., $18(4), 1212-1226$ 
Schneider, B., Schlitzer, R., Fischer, G., Nöthig, E.M., 2003. Depth-dependent elemental compositions of particulate organic matter (POM) in the ocean. Global Biogeochem. Cycles $17,1032$.

Šimek, K., Chrzanowski, T.H., 1992. Direct and indirect evidence of size-selective grazing on pelagic bacteria by freshwater nanoflagellates. Appl. Environ. Microbiol. 58, 3715-3720.

Small, G.E., Bullerjahn, G.S., Sterner, R.W., Beall, B.F., Brovold, S., Finlay, J.C., McKay, R.M. and Mukherjee, M., 2013. Rates and controls of nitrification in a large oligotrophic lake. Limnology and oceanography, 58(1), 276-286.

Smith, S.D., McIntyre, P.B., Halpern, B.S., Cooke, R.M., Marino, A.L., Boyer, G.L., Buchsbaum, A., Burton Jr, G., Campbell, L.M., Ciborowski, J.J., 2015. Rating impacts in a multi-stressor world: a quantitative assessment of 50 stressors affecting the Great Lakes. Ecol. Appl. 25, 717-728.

Sogin, M.L., Morrison, H.G., Huber, J.A., Welch, D.M., Huse, S.M., Neal, P.R., Arrieta, J.M., Herndl, G.J., 2006. Microbial diversity in the deep sea and the underexplored "rare biosphere”. Proc. Natl. Acad. Sci. USA 103, 12115-12120.

Steinman, A.D., Ogdahl, M., Rediske, R., Ruetz, C.R., Biddanda, B.A., Nemeth, L., 2008. Current status and trends in Muskegon Lake, Michigan. J. Great Lakes Res. 34, 169-188.

Tranvik, L.J., Downing, J.A., Cotner, J.B., Loiselle, S.A., Striegl, R.G., Ballatore, T.J., Dillon, P., Finlay, K., Fortino, K., Knoll, L.B., 2009. Lakes and reservoirs as regulators of carbon cycling and climate. Limnol. Oceanogr. 54, 2298-2314.

Tremblay, J., Singh, K., Fern, A., Kirton, E.S., He, S., Woyke, T., Lee, J., Chen, F., Dangl, J.L., and Tringe, S.G. 2015. Primer and platform effects on 16S rRNA tag sequencing. Front. Microbiol. 6. 771. 
Turner, J.T., 2015. Zooplankton fecal pellets, marine snow, phytodetritus and the ocean's biological pump. Prog. Oceanogr. 130, 205-248.

Turschak, B.A., Bunnell, D., Czesny, S., Höök, T.O., Janssen, J., Warner, D., Bootsma, H.A., 2014. Nearshore energy subsidies support Lake Michigan fishes and invertebrates following major changes in food web structure. Ecology 95, 1243-1252.

Vanderploeg, H., Johengen, T., Lavrentyev, P.J., Chen, C., Lang, G., Agy, M., Bundy, M., Cavaletto, J., Eadie, B., Liebig, J., 2007. Anatomy of the recurrent coastal sediment plume in Lake Michigan and its impacts on light climate, nutrients, and plankton. J. Geophys. Res. 112, C03S90.

Vanderploeg, H.A., Liebig, J.R., Carmichael, W.W., Agy, M.A., Johengen, T.H., Fahnenstiel, G.L., Nalepa, T.F., 2001. Zebra mussel (Dreissena polymorpha) selective filtration promoted toxic Microcystis blooms in Saginaw Bay (Lake Huron) and Lake Erie. Can. J. Fish. Aquat. Sci. $58,1208-1221$.

Vanderploeg H.A., Ludsin S.A., Ruberg S.A., Hoeoek T.O., Pothoven S.A., Brandt S.B., Lang G.A., Liebig J.R. \& Cavaletto J.F., 2009. Hypoxia affects spatial distributions and overlap of pelagic fish, zooplankton, and phytoplankton in Lake Erie. J Exp Mar Biol Ecol, 381, S92S107.

Vanderploeg, H.A., Liebig, J.R., Nalepa, T.F., Fahnenstiel, G.L., Pothoven, S.A., 2010. Dreissena and the disappearance of the spring phytoplankton bloom in Lake Michigan. J. Great Lakes Res. 36, 50-59.

Weinke, A.D., Kendall, S.T., Kroll, D.J., Strickler, E.A., Weinert, M.E., Holcomb, T.M., Defore, A.A., Dila, D.K., Snider, M.J., Gereaux, L.C., Biddanda, B.A., 2014. Systematically variable 
planktonic carbon metabolism along a land-to-lake gradient in a Great Lakes coastal zone. J. Plankton Res. fbu066.

Wickham, H. 2009. ggplot2: Elegant Graphics for Data Analysis. New York, NY: Springer.

Wilhelm, S.W., LeCleir, G.R., Bullerjahn, G.S., McKay, R.M., Saxton, M.A., Twiss, M.R., Bourbonniere, R.A., 2014. Seasonal changes in microbial community structure and activity imply winter production is linked to summer hypoxia in a large lake. FEMS Microbiol Ecol 87: 475-485.

Yannarell, A., Kent, A., Lauster, G., Kratz, T., Triplett, E., 2003. Temporal patterns in bacterial communities in three temperate lakes of different trophic status. Microb. Ecol. 46, 391-405. 


\section{Tables and Figures}

Table 1. Summary of samples and environmental data. At each sampling event, a particleassociated (PA) and free-living (FL) fraction was collected (Su.PA.M110.D.N failed to amplify) and two replicate extractions and sequencing libraries were generated (* only one replicate available). Geochemical data originated from laboratory analyses, temperature (T) was determined using a CTD cast, and dissolved oxygen (DO) and photosynthetically-active radiation $(\mathrm{PAR})$ derived from the plankton survey system data. Sample names: $\mathrm{Sp}=\mathrm{Spring}, \mathrm{Su}=$ Summer, Fa $=$ Fall; MLB = Muskegon Lake Buoy, M15 = $15 \mathrm{~m}$ depth station Lake Michigan, M110 = 110 m depth station Lake Michigan; S = Surface, D = Deep, M= chlorophyll maximum; $\mathrm{D}=$ day, $\mathrm{N}=$ night. Environmental data: $\mathrm{Chl}=\operatorname{chl} a, \mathrm{TP}=$ total phosphorus, $\mathrm{PP}=$ particulate phosphorus, $\mathrm{POC}=$ particulate organic carbon, $\mathrm{DOC}=$ dissolved organic carbon, $\mathrm{PON}=$ particulate organic nitrogen, TSS = total suspended solids. Nutrients were only analyzed once per station (so day and night samples for microbial community analysis have the same nutrient values). ** Summer and fall geochemistry was determined on samples taken at 90 and $80 \mathrm{~m}$ depth, respectively.

\begin{tabular}{|c|c|c|c|c|c|c|c|c|c|c|c|c|c|c|c|}
\hline Sampling event & $\begin{array}{c}\text { Dat } \\
\text { e }\end{array}$ & $\underset{\mathbf{e}}{\mathrm{Tim}}$ & $\begin{array}{c}\text { Dept } \\
\text { h } \\
(\mathrm{m}) \\
\end{array}$ & $\begin{array}{c}\text { Volu } \\
\text { me } \\
(\mathrm{L})\end{array}$ & $\begin{array}{c}\mathrm{T} \\
\left({ }^{\circ} \mathrm{C}\right)\end{array}$ & $\begin{array}{c}\text { DO } \\
(\mathrm{mg} / \\
\mathrm{L})\end{array}$ & $\begin{array}{c}\text { Chl } \\
(\mu \mathrm{g} / \\
\mathrm{L})\end{array}$ & $\begin{array}{c}\text { TP } \\
(\mu \mathrm{g} / \\
\mathrm{L})\end{array}$ & $\begin{array}{c}\text { PP } \\
(\mu \mathrm{g} / \\
\mathrm{L})\end{array}$ & $\begin{array}{c}\text { POC } \\
\text { (mg/ } \\
\mathrm{L})\end{array}$ & $\begin{array}{c}\text { DOC } \\
\text { (mg/ } \\
\mathrm{L})\end{array}$ & $\begin{array}{c}\text { PON } \\
\text { (mg/ } \\
\text { L) }\end{array}$ & $\begin{array}{c}\mathrm{SiO}_{2} \\
(\mathrm{mg} / \\
\mathrm{L})\end{array}$ & $\begin{array}{c}\text { TSS } \\
(\mathrm{mg} / \\
\mathrm{L})\end{array}$ & $\begin{array}{c}\text { PAR } \\
\text { (W/m } \\
2)\end{array}$ \\
\hline $\begin{array}{c}\text { Sp.FL/PA.MLB. } \\
\text { S.N }\end{array}$ & $\begin{array}{c}4 / 2 \\
4\end{array}$ & $\begin{array}{l}2: 09 \\
\text { AM }\end{array}$ & 5 & 2.8 & - & - & - & - & - & - & - & - & - & - & - \\
\hline $\begin{array}{c}\text { Sp.FL/PA.M15.S } \\
\text {.N }\end{array}$ & $\begin{array}{c}4 / 2 \\
4\end{array}$ & $\begin{array}{l}1: 10 \\
\text { AM }\end{array}$ & 5 & 4 & 5.59 & $\begin{array}{c}15.0 \\
0\end{array}$ & 5.67 & $\begin{array}{c}27.8 \\
2\end{array}$ & $\begin{array}{c}22.3 \\
0\end{array}$ & 0.59 & 3.66 & 0.08 & 2.53 & 7.30 & 0.00 \\
\hline $\begin{array}{c}\text { Sp.FL/PA.M15.S } \\
\text {.D }\end{array}$ & $\begin{array}{c}4 / 2 \\
3\end{array}$ & $\begin{array}{l}10: 4 \\
0 \\
\text { AM }\end{array}$ & 5 & 7.5 & 4.82 & $\begin{array}{c}15.0 \\
0\end{array}$ & 5.67 & $\begin{array}{c}27.8 \\
2\end{array}$ & $\begin{array}{c}22.3 \\
0\end{array}$ & 0.59 & 3.66 & 0.08 & 2.53 & 7.30 & 25.78 \\
\hline $\begin{array}{c}\text { Sp.FL/PA.M15.D } \\
\text {.D }\end{array}$ & $\begin{array}{c}4 / 2 \\
3\end{array}$ & $\begin{array}{l}1: 30 \\
\mathrm{PM}\end{array}$ & 10 & 9.5 & 4.82 & $\begin{array}{c}15.0 \\
0\end{array}$ & - & - & - & - & - & - & - & - & 1.29 \\
\hline $\begin{array}{c}\text { Sp.FL/PA*.M110 } \\
\text {.S.N }\end{array}$ & $\begin{array}{c}4 / 2 \\
3\end{array}$ & $\begin{array}{l}10: 0 \\
0 \\
\text { PM }\end{array}$ & 5 & 7.5 & 2.71 & $\begin{array}{c}13.5 \\
0\end{array}$ & 0.68 & 3.42 & 1.80 & 0.09 & 2.22 & 0.01 & 1.82 & 0.12 & 0.00 \\
\hline $\begin{array}{l}\text { Sp.FL/PA.M110. } \\
\text { S.D }\end{array}$ & $\begin{array}{c}4 / 2 \\
3\end{array}$ & $\begin{array}{l}5: 45 \\
\text { PM }\end{array}$ & 5 & 8.5 & 2.81 & $\begin{array}{c}13.5 \\
0\end{array}$ & 0.68 & 3.42 & 1.80 & 0.09 & 2.22 & 0.01 & 1.82 & 0.12 & 15.99 \\
\hline $\begin{array}{c}\text { Sp.FL*/PA.M110 } \\
\text {.D.D }\end{array}$ & $\begin{array}{c}4 / 2 \\
3\end{array}$ & $\begin{array}{l}6: 36 \\
\text { PM }\end{array}$ & 108 & 9 & 3.17 & $\begin{array}{c}15.0 \\
0\end{array}$ & - & - & - & - & - & - & - & - & 0.00 \\
\hline $\begin{array}{c}\text { Su.FL*/PA.MLB. } \\
\text { S.D }\end{array}$ & $\begin{array}{c}7 / 1 \\
5\end{array}$ & $\begin{array}{l}6: 15 \\
\text { PM }\end{array}$ & 1 & 10 & $\begin{array}{c}27.9 \\
9\end{array}$ & 8.64 & - & - & - & - & - & - & - & - & $\begin{array}{c}1042 . \\
60\end{array}$ \\
\hline $\begin{array}{c}\text { Su.FL*/PA.MLB. } \\
\text { D.D }\end{array}$ & $\begin{array}{c}7 / 1 \\
5\end{array}$ & $\begin{array}{l}6: 55 \\
\mathrm{PM}\end{array}$ & 8 & 8.5 & $\begin{array}{c}17.5 \\
6\end{array}$ & -0.42 & - & - & - & - & - & - & - & - & 0.04 \\
\hline $\begin{array}{c}\text { Su.FL/PA.M15.S } \\
. \mathrm{N}\end{array}$ & $\begin{array}{c}7 / 1 \\
5\end{array}$ & $\begin{array}{l}9: 25 \\
\text { PM }\end{array}$ & 5 & 10 & $\begin{array}{c}16.9 \\
9\end{array}$ & 9.24 & 2.38 & 5.86 & 3.90 & 0.38 & 6.13 & 0.05 & 1.12 & 1.12 & 85.08 \\
\hline
\end{tabular}




\begin{tabular}{|c|c|c|c|c|c|c|c|c|c|c|c|c|c|c|c|}
\hline $\begin{array}{c}\text { Su.FL/PA.M15.S } \\
\text {.D }\end{array}$ & $\begin{array}{c}7 / 1 \\
6\end{array}$ & $\begin{array}{l}2: 35 \\
\text { PM }\end{array}$ & 5 & 10 & $\begin{array}{c}16.0 \\
6\end{array}$ & 7.34 & 2.38 & 5.86 & 3.90 & 0.38 & 6.13 & 0.05 & 1.12 & 1.12 & $\begin{array}{c}834.8 \\
3\end{array}$ \\
\hline $\begin{array}{c}\text { Su.FL/PA.M15.D } \\
\text {.N }\end{array}$ & $\begin{array}{c}7 / 1 \\
5\end{array}$ & $\begin{array}{l}10: 0 \\
0 \\
\text { PM }\end{array}$ & 15 & 10 & 9.13 & $\begin{array}{c}10.1 \\
9\end{array}$ & - & - & - & - & - & - & - & - & 9.62 \\
\hline $\begin{array}{c}\text { Su.FL/PA.M110. } \\
\text { S.N }\end{array}$ & $\begin{array}{c}7 / 1 \\
6\end{array}$ & $\begin{array}{l}3: 25 \\
\text { AM }\end{array}$ & 5 & 10 & $\begin{array}{c}21.9 \\
1\end{array}$ & 8.19 & 1.03 & 5.08 & 3.08 & 0.21 & 2.52 & 0.03 & 1.25 & 0.56 & 0.00 \\
\hline $\begin{array}{c}\text { Su.FL/PA.M110. } \\
\text { S.D }\end{array}$ & $\begin{array}{c}7 / 1 \\
6\end{array}$ & $\begin{array}{l}8: 41 \\
\text { AM }\end{array}$ & 5 & 10 & $\begin{array}{c}20.8 \\
8\end{array}$ & 7.67 & 1.03 & 5.08 & 3.08 & 0.21 & 2.52 & 0.03 & 1.25 & 0.56 & $\begin{array}{c}134.8 \\
3\end{array}$ \\
\hline $\begin{array}{l}\text { Su.FL/PA.M110. } \\
\text { M.D }\end{array}$ & $\begin{array}{c}7 / 1 \\
6\end{array}$ & $\begin{array}{c}9: 20 \\
\text { AM }\end{array}$ & 36 & 10 & 5.65 & $\begin{array}{c}11.4 \\
0\end{array}$ & 2.96 & 5.16 & 2.68 & 0.19 & 2.14 & 0.03 & 1.82 & 0.58 & 4.04 \\
\hline Su.FL.M110.D.N & $\begin{array}{c}7 / 1 \\
6\end{array}$ & $\begin{array}{c}4: 03 \\
\text { AM }\end{array}$ & $\underset{*}{110^{*}}$ & 10 & 4.28 & $\begin{array}{c}11.3 \\
4\end{array}$ & 0.24 & 2.99 & 1.41 & 0.05 & 2.11 & 0.01 & 1.85 & 0.10 & 0.00 \\
\hline $\begin{array}{c}\text { Fa.FL*/PA.MLB. } \\
\text { S.N }\end{array}$ & $\begin{array}{c}9 / 2 \\
3\end{array}$ & $\begin{array}{l}7: 45 \\
\text { PM }\end{array}$ & 2 & 10 & $\begin{array}{c}18.6 \\
1\end{array}$ & - & - & - & - & - & - & - & - & - & 2.70 \\
\hline $\begin{array}{c}\text { Fa.FL*/PA.MLB. } \\
\text { D.N }\end{array}$ & $\begin{array}{c}9 / 2 \\
3\end{array}$ & $\begin{array}{l}\text { 8:10 } \\
\text { PM }\end{array}$ & 8 & 10 & $\begin{array}{c}17.0 \\
8\end{array}$ & - & - & - & - & - & - & - & - & - & 0.00 \\
\hline $\begin{array}{c}\text { Fa.FL/PA.M15.S } \\
\text {.N }\end{array}$ & $\begin{array}{c}9 / 2 \\
3\end{array}$ & $\begin{array}{l}9: 18 \\
\text { PM }\end{array}$ & 5 & 11 & $\begin{array}{c}13.0 \\
1\end{array}$ & $\begin{array}{c}14.5 \\
0\end{array}$ & 1.33 & 4.15 & 2.93 & 0.26 & 2.07 & 0.03 & 1.46 & 0.53 & 0.00 \\
\hline $\begin{array}{c}\text { Fa.FL/PA.M15.S } \\
\text {.D }\end{array}$ & $\begin{array}{c}9 / 2 \\
4\end{array}$ & $\begin{array}{l}1: 30 \\
\text { PM }\end{array}$ & 5 & 9 & $\begin{array}{c}14.3 \\
2\end{array}$ & $\begin{array}{c}14.5 \\
0\end{array}$ & 1.33 & 4.15 & 2.93 & 0.26 & 2.07 & 0.03 & 1.46 & 0.53 & $\begin{array}{c}417.7 \\
2\end{array}$ \\
\hline $\begin{array}{c}\text { Fa.FL/PA.M15.D } \\
\text {.N }\end{array}$ & $\begin{array}{c}9 / 2 \\
3\end{array}$ & $\begin{array}{l}10: 0 \\
0 \\
\mathrm{PM}\end{array}$ & 15 & 10 & $\begin{array}{c}12.0 \\
0\end{array}$ & $\begin{array}{c}14.5 \\
0\end{array}$ & - & - & - & - & - & - & - & - & - \\
\hline $\begin{array}{c}\text { Fa.FL/PA.M110. } \\
\text { S.N }\end{array}$ & $\begin{array}{c}9 / 2 \\
4\end{array}$ & $\begin{array}{c}3: 04 \\
\text { AM }\end{array}$ & 5 & 10 & $\begin{array}{c}15.0 \\
0\end{array}$ & $\begin{array}{c}13.5 \\
0\end{array}$ & 1.17 & 4.77 & 2.55 & 0.38 & 2.11 & 0.05 & 1.18 & 0.58 & 0.00 \\
\hline $\begin{array}{c}\text { Fa.FL/PA.M110. } \\
\text { S.D }\end{array}$ & $\begin{array}{c}9 / 2 \\
4\end{array}$ & $\begin{array}{c}9: 28 \\
\text { AM }\end{array}$ & 5 & 10.5 & $\begin{array}{c}17.3 \\
3\end{array}$ & $\begin{array}{c}13.5 \\
0\end{array}$ & 1.17 & 4.77 & 2.55 & 0.38 & 2.11 & 0.05 & 1.18 & 0.58 & 19.83 \\
\hline $\begin{array}{c}\text { Fa.FL/PA.M110. } \\
\text { D.N }\end{array}$ & $\begin{array}{c}9 / 2 \\
4\end{array}$ & $\begin{array}{c}4: 02 \\
\text { AM }\end{array}$ & $\underset{*}{108^{*}}$ & 10.5 & 4.27 & $\begin{array}{c}15.0 \\
0\end{array}$ & 0.16 & 2.55 & 0.88 & 0.07 & 1.85 & 0.01 & 1.94 & 0.09 & 0.00 \\
\hline
\end{tabular}


Table 2: Nested PERMANOVA analysis of bacterial community dissimilarity. $\mathrm{R}^{2}$ and $\mathrm{p}$ values in parentheses for PERMANOVA analysis performed on the data after removal of taxa with average relative abundances $<0.1 \%$ (139 OTUs retained). ${ }^{*} \mathrm{Sp}=$ spring, $\mathrm{Su}=$ summer, $\mathrm{Fa}=$ fall; " $\mathrm{ML}=$ Muskegon Lake, $\mathrm{LM}=$ Lake Michigan; "' $\mathrm{S}=$ surface, $\mathrm{M}=$ chlorophyll maximum, $\mathrm{D}=$ deep.

\begin{tabular}{|c|c|c|c|c|c|c|c|}
\hline Factor & Fraction & Season $^{*}$ & Lake $^{* *}$ & Station & Depth $^{* * *}$ & Diel & Residuals \\
\hline Values & $P A, F L$ & $S p, S u, F a$ & $M L, L M$ & $M L B, M 15, M 110$ & $S, M, D$ & Day, Night & - \\
\hline Bray-Curtis (n = 47) & $\begin{array}{c}0.28 \\
(0.001)\end{array}$ & $\begin{array}{c}0.2 \\
(0.001)\end{array}$ & $\begin{array}{c}0.08 \\
(0.001)\end{array}$ & $\begin{array}{c}0.03 \\
(0.007)\end{array}$ & $\begin{array}{c}0.05 \\
(0.006)\end{array}$ & $\begin{array}{c}0.01 \\
(0.445)\end{array}$ & 0.36 \\
\hline Sørensen (n= 47) & $\begin{array}{c}0.11 \\
(0.001)\end{array}$ & $\begin{array}{c}0.31 \\
(0.001)\end{array}$ & $\begin{array}{c}0.20 \\
(0.001)\end{array}$ & $\begin{array}{c}0.06 \\
(0.001)\end{array}$ & $\begin{array}{c}0.06 \\
(0.002)\end{array}$ & $\begin{array}{c}0.01 \\
(0.214)\end{array}$ & 0.25 \\
\hline
\end{tabular}


Table 3: Summary of BIOENV analyses. Spearman correlations of between-sample physical and geochemical differences (Euclidean distance) and community composition differences (BrayCurtis dissimilarity, 139 OTUs $>0.1 \%$ average abundance). The best combination of parameters is shown for analyses using all samples (PA and FL), and separate analyses per fraction (PA, FL). P-values supporting whether the correlation coefficient were significantly different from zero were determined using a random permutation test. The boldface type parameter is the strongest single correlating factor (correlation coefficient and p-value between parentheses). Analyses only included samples for which data was available for all environmental factors (see Table 1).

\begin{tabular}{|c|c|c|c|c|}
\hline $\begin{array}{l}\text { Biological } \\
\text { data }\end{array}$ & Environmental factors & Best match & $\mathbf{R}$ & $P$ value \\
\hline$P A$ and $F L$ & \multirow{3}{*}{$\begin{array}{c}\text { T, DO, log(Chla), } \log (\text { TP), POC, PON, } \log (\mathrm{DOC}), \text { SiO2, } \\
\log (\mathrm{TSS}), \log (\mathrm{PAR})\end{array}$} & $\begin{array}{c}\text { T, DO, log(Chla), } \\
\text { log(DOC) }\end{array}$ & $\begin{array}{l}0.14 \\
(0.12)\end{array}$ & $0.26(0.38)$ \\
\hline PA & & $\mathbf{T}, \log (\mathrm{TSS})$ & $\begin{array}{c}0.77 \\
(0.62) \\
\end{array}$ & $\begin{array}{l}<0.01 \\
(<0.01)\end{array}$ \\
\hline FL & & $\mathrm{T}, \log (\mathrm{Chla}), \mathrm{SiO}_{2}$ & $\begin{array}{c}0.76 \\
(0.64)\end{array}$ & $\begin{array}{l}<0.01 \\
(<0.01)\end{array}$ \\
\hline
\end{tabular}


Figure 1. Sampling sites and sonde data. (A-B) Map (C) Google) of Great Lakes region with detail of the Muskegon Lake freshwater estuary and the NOAA GLERL Lake Michigan transect. (C) Water temperature and derived chla obtained from the Muskegon Lake Buoy, which was deployed from May 15 until November 2, 2013. Summer and Fall sampling dates are highlighted in red. (D-F) Lake Michigan water temperature profiles and (G-I) derived chla at the times of sampling, as measured using the plankton survey system data. Red and black circles indicate the sampling stations on the profiles.

Figure 2. Observed bacterial richness and Simpson's evenness. (A-D) Observed richness and (EH) Simpson's evenness comparisons based on (A,E) season, $(\mathrm{B}, \mathrm{F})$ sampling station, $(\mathrm{C}, \mathrm{G})$ filter fractions $(\mathrm{FL}=$ free-living, $\mathrm{PA}=$ particle-associated $)$, and $(\mathrm{D}, \mathrm{H})$ sampling depth (See table 1 for specific depths). Individual sample data was plotted within boxplots and colored by season. Letter(s) below each boxplot identify sample groups within each plot that have significantly different median richness or evenness, as determined by pairwise post-hoc testing $(\mathrm{p}<0.05)$ of the Kruskall-Wallis test results. All libraries were rarefied to the smallest library size after merging of replicates $(70,480$ sequences $)$.

Figure 3. Principal coordinates analysis (PCoA). Ordinations of the first two coordinates based on Bray-Curtis dissimilarity between bacterial communities. The analysis only included the 139 OTUs with average relative abundance $>0.1 \%$. Percentages next to each coordinate label indicate $\%$ of total sample variation represented by the coordinate. Panel A contrasts fraction and seasons, while panel B contrasts stations and sampling depths. 


\section{Figure 4: Dissimilarities between surface communities along the transect over time.}

Boxplots represent the Bray-Curtis dissimilarities between samples when considering the 139 OTUs $>0.1 \%$ average relative abundance. Within each season, dissimilarities were determined between samples obtained from surface water at the estuary (MLB), nearshore (M15) and offshore (M110) station. Comparisons were made within each fraction, not between. Letter(s) below boxplots differentiate sample groups that differ significantly in dissimilarity (i.e., between station comparisons with significantly different medians do not share any letters), as determined by pairwise post-hoc testing $(\mathrm{p}<0.05)$ of the Kruskall-Wallis test results.

Figure 5. Dissimilarities among and between PA and FL fraction communities. (A) Boxplots represent the Bray-Curtis dissimilarities between samples when considering the 139 OTUs $>0.1$ $\%$ average relative abundance. Dissimilarities were determined within the FL fraction and within the PA fraction (X-axis). Data points within each boxplot were colored to allow evaluation of matching comparisons for the PA and FL fractions. The comparisons from left to right are listed in the legend from top to bottom, from more similar (same season and station), to more dissimilar (different season, different station). The medians of FL and PA dissimilarities significantly differed (Kruskall-Wallis test, $\mathrm{p}<0.05$ ). (B) Differential abundance of OTUs categorized by functional group based on carbon and energy source. Energy source: $\mathrm{O}=$ chemoorganotroph, $\mathrm{P}=$ phototroph $(\mathrm{BR}=$ bacteriorhodopsin, $\mathrm{C}=\operatorname{chl} a, \mathrm{BC}=$ bacteriochlorophyll), $\mathrm{L}=$ chemolithotroph $\left(\mathrm{S}=\right.$ sulphur, $\left.\mathrm{N}=\mathrm{NH}_{4}{ }^{+}\right)$. 
Figure 6: Differential abundance of OTUs categorized by functional group based on carbon and energy source. OTUs with average relative abundance across all samples $>0.1 \%$ were included for analysis of differences in relative abundance using DEseq. Comparison were made separately for (A, C, E, G) FL and (B, D, F, H) PA communities between (A,B) lake, (C-F) seasons, and $(\mathrm{G}, \mathrm{H})$ depth while controlling for variation of all other factors. See Table S2 for details on functional group classification. Energy source: $\mathrm{O}=$ chemoorganotroph, $\mathrm{P}=$ phototroph $(\mathrm{BR}=$ bacteriorhodopsin, $\mathrm{CHL}=\operatorname{chl} a, \mathrm{BCHL}=$ bacteriochlorophyll $), \mathrm{L}=$ chemolithotroph $(\mathrm{S}=$ sulphur, $\mathrm{N}=\mathrm{NH}_{4}^{+}{ }^{+}$. Numbers next to X-axis category labels indicate number of OTUs that were significantly $(\mathrm{p}<0.01)$ more abundant in that category.

Figure 7: Line plots of select OTUs. Relative abundance of OTUs across space and time. Plot background color reflects energy source. 


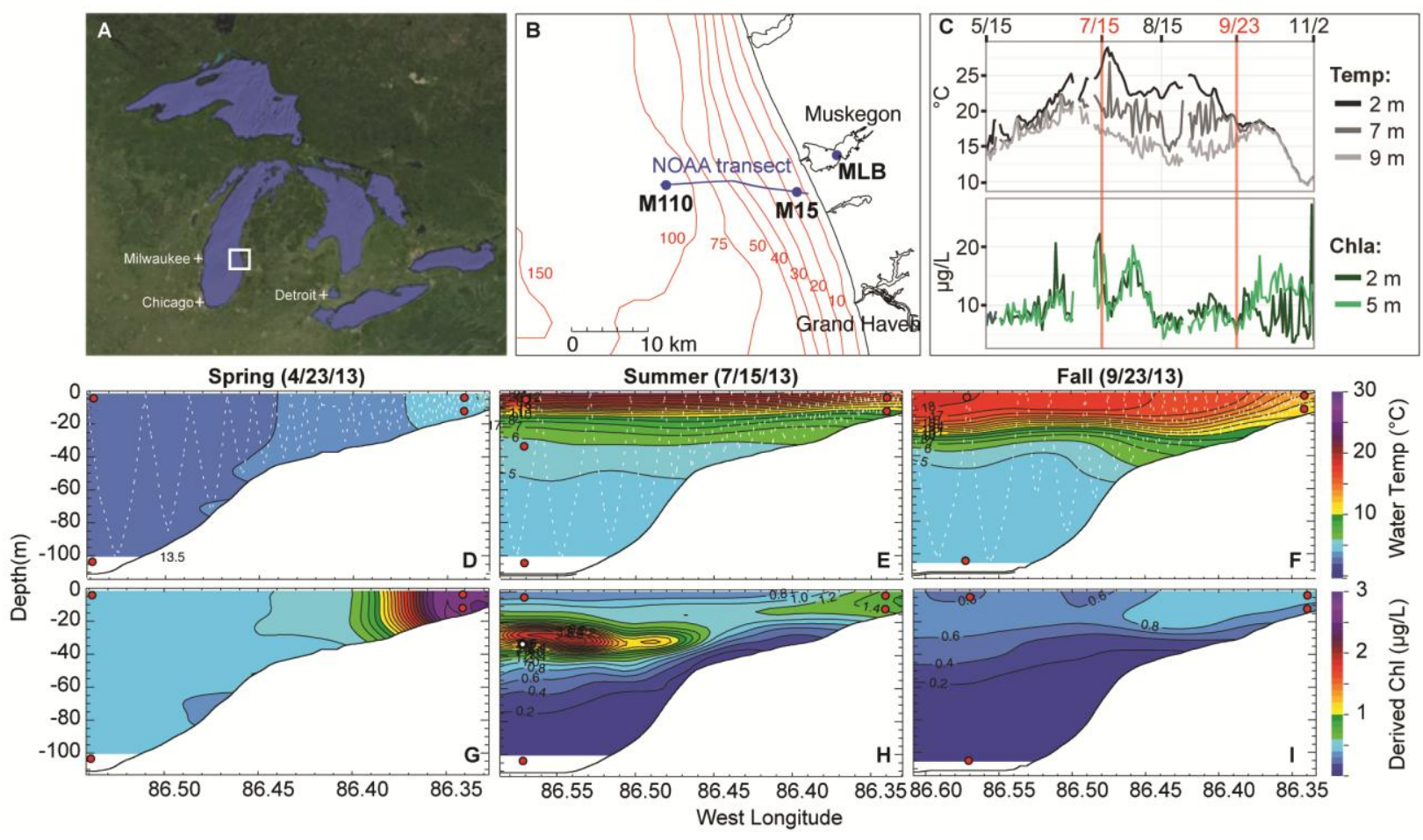



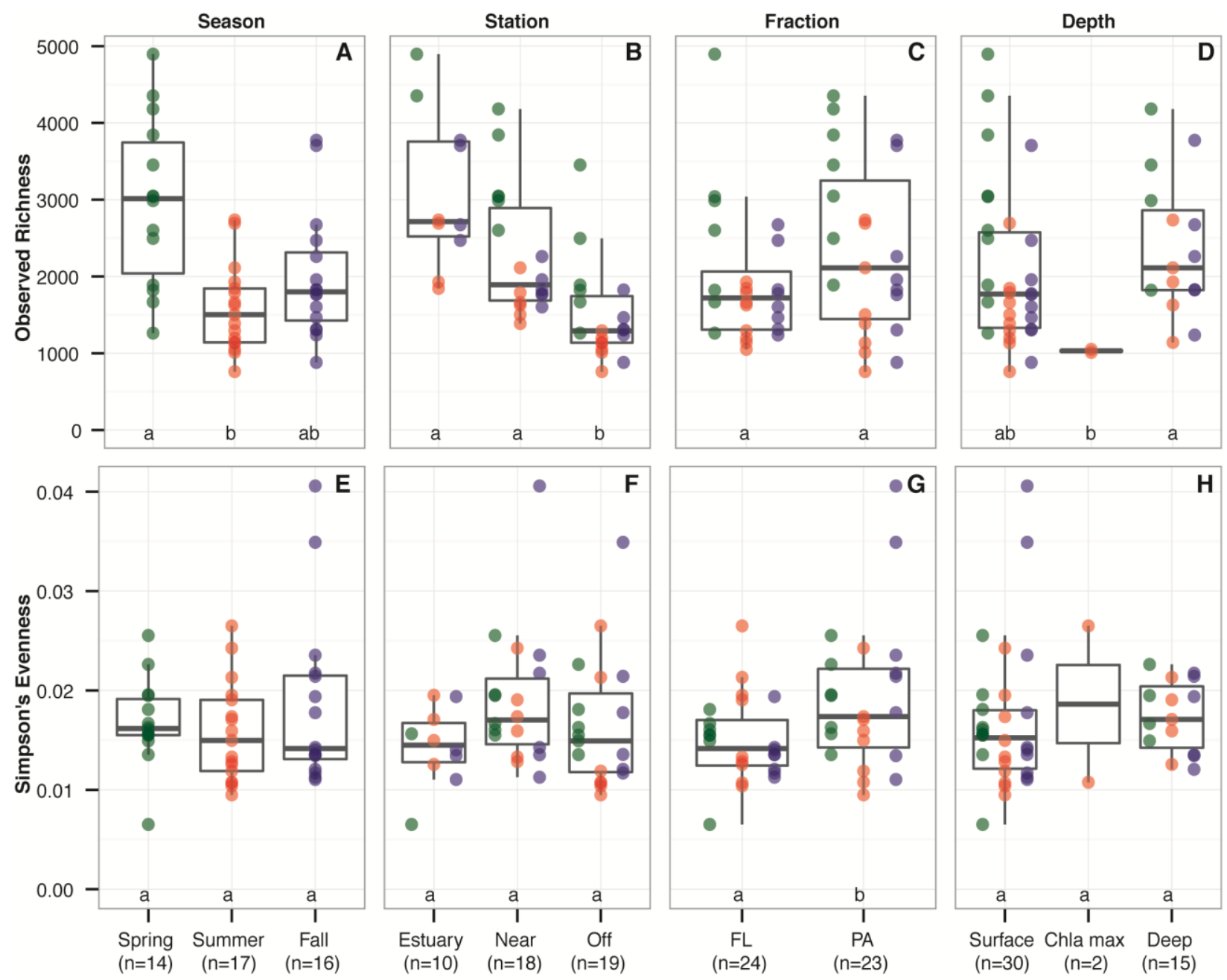


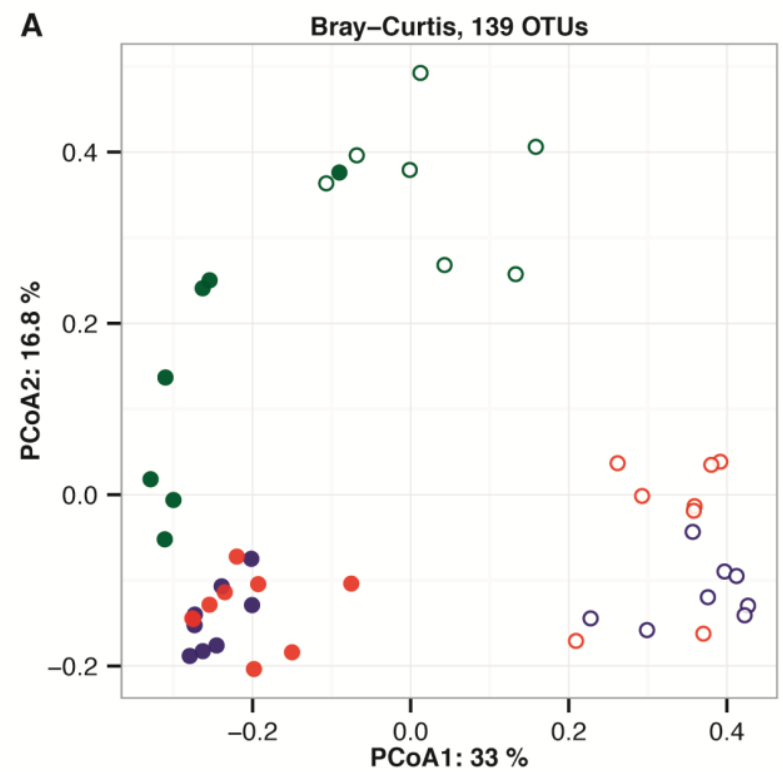

Season: $\bullet$ Spring $\bullet$ Summer $\bullet$ Fall

Fraction: $\mathrm{OPA} \bullet \mathrm{FL}$

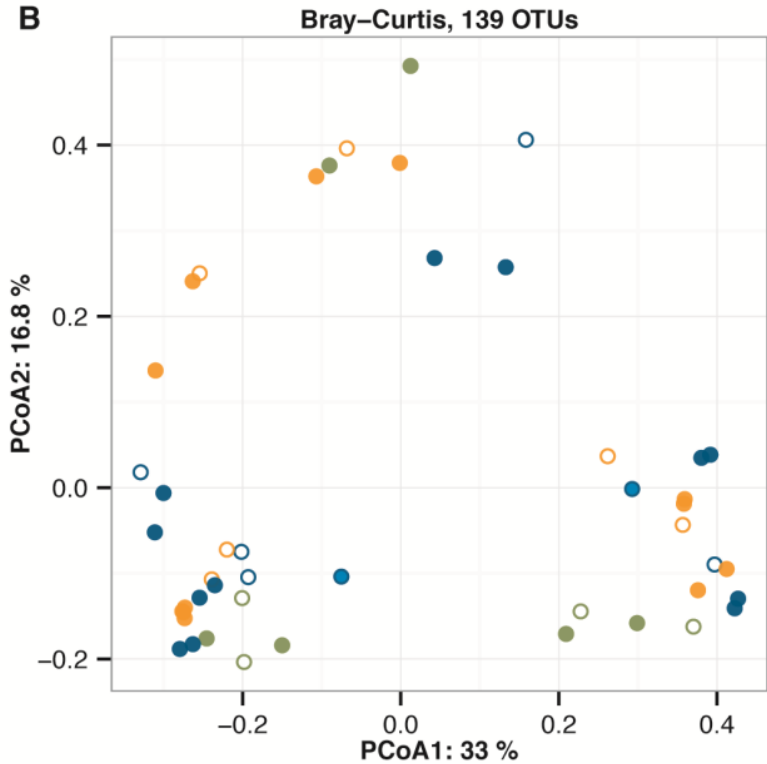

Station: $\bullet$ MLB M15 M110 Depth: OSurface $\bullet$ Deep $\bullet$ Chla max 


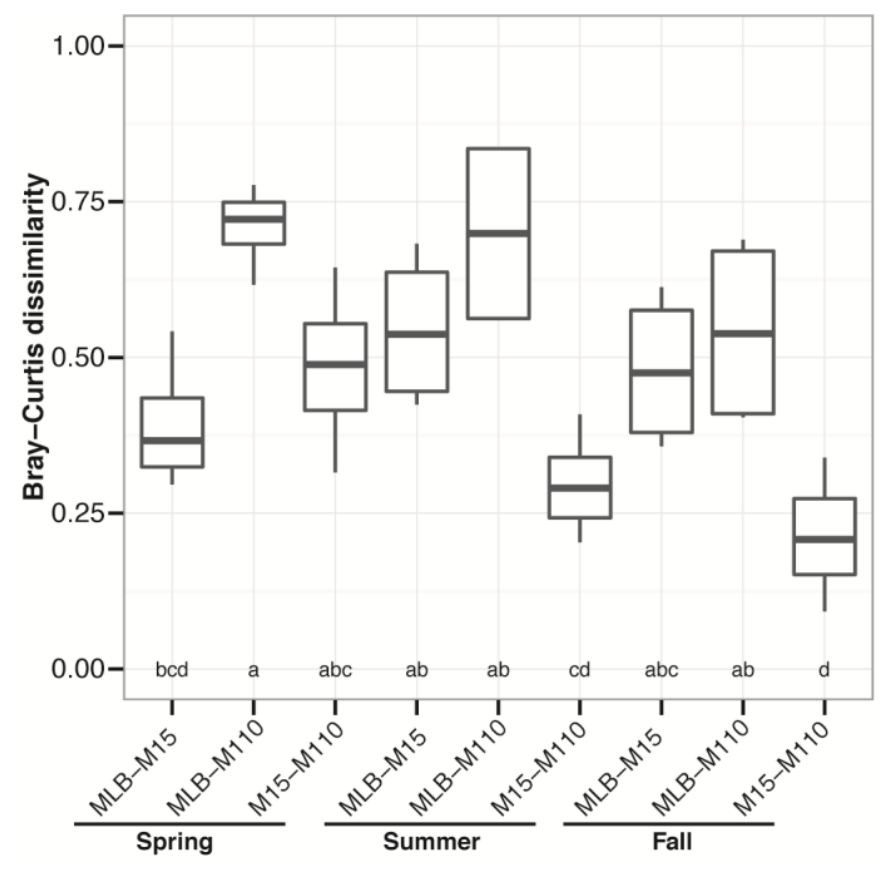



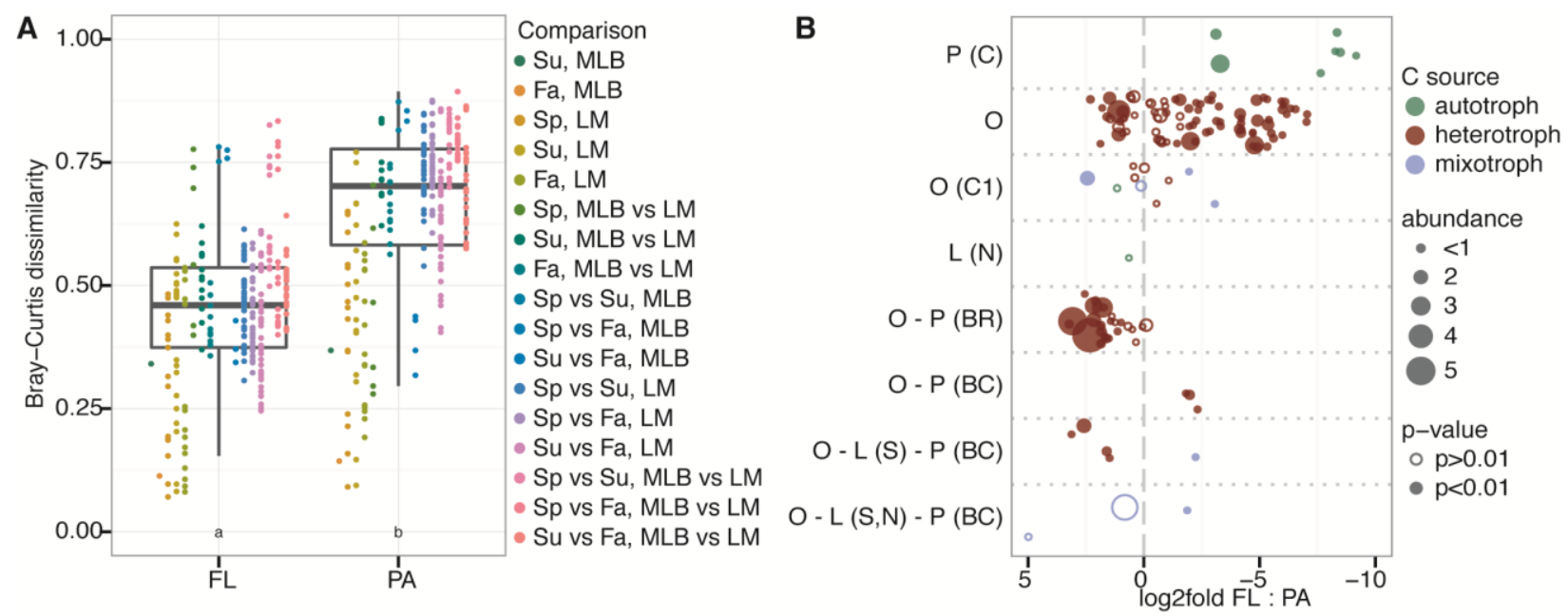
C source: $\bigcirc$ autotroph heterotroph mixotroph p-value: $\bigcirc p>0.01 \bigcirc p<0.01$ Mean abundance $(\%): \bullet<1 \bigcirc 2 \bigcirc 3 \bigcirc 4 \bigcirc 5$
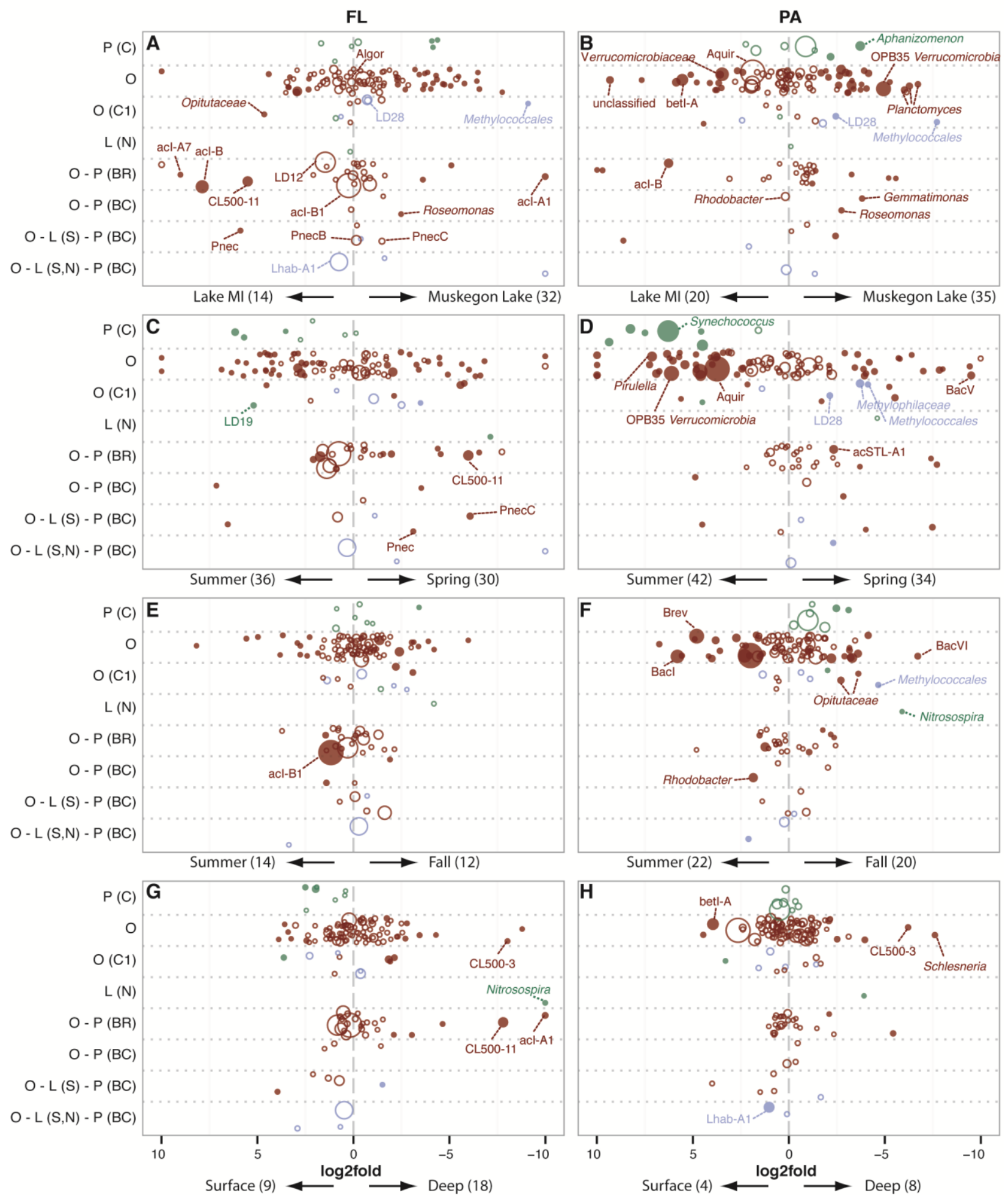


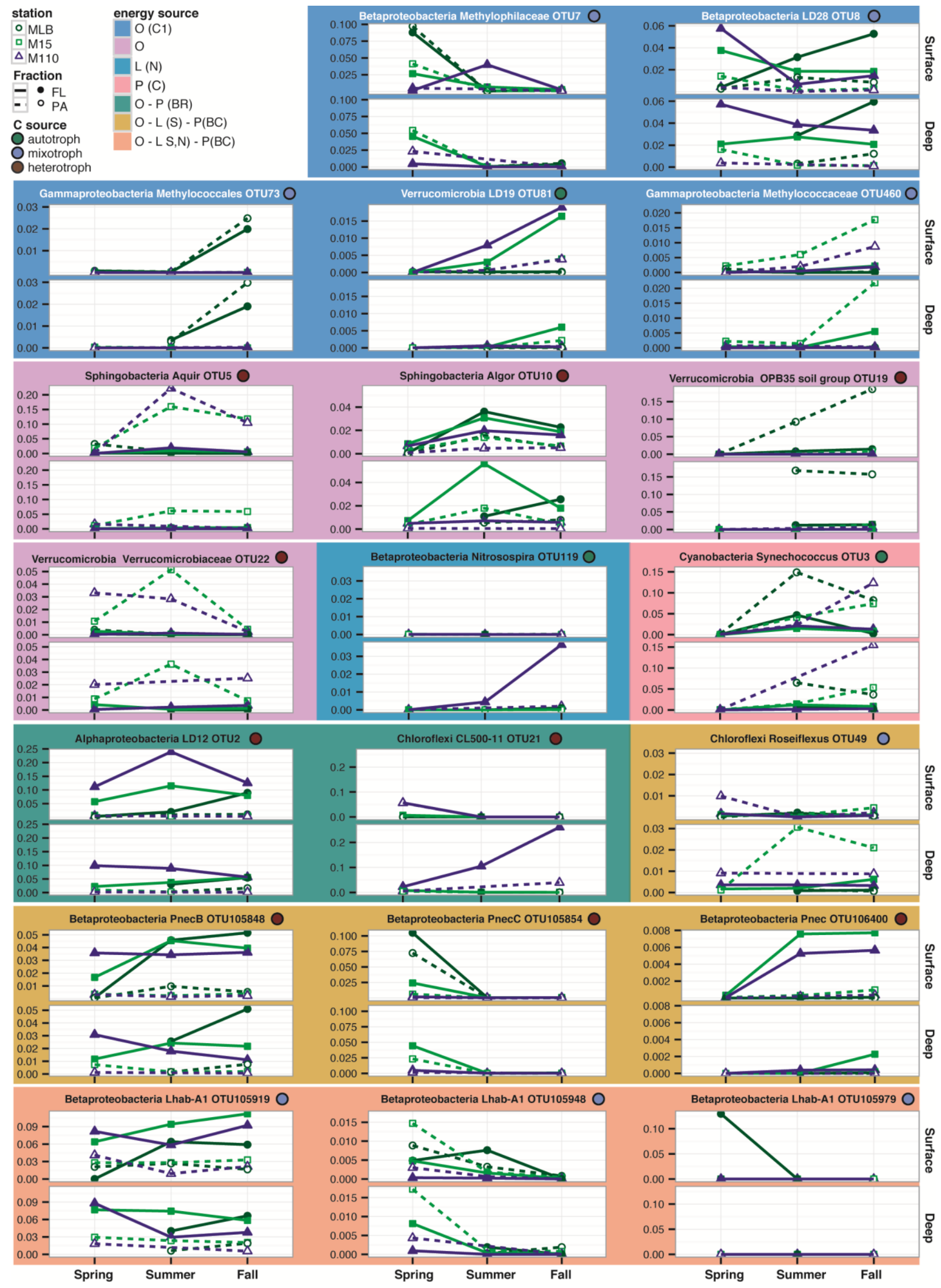

